\title{
Isoprene fluxes from warm temperate and tropical seagrass communities
}

\author{
Victoria Hrebien*, Elisabeth Deschaseaux, Bradley D. Eyre \\ Centre for Coastal Biogeochemistry, Faculty of Science and Engineering, Southern Cross University, \\ Lismore, NSW 2480, Australia
}

\begin{abstract}
Isoprene is an important biogenic volatile organic compound (BVOC), with a contribution to annual greenhouse gas emissions similar to that of methane in terms of carbon equivalent. Isoprene is mostly produced by terrestrial vegetation, although marine ecosystems also play an important role in isoprene production. Here, we report isoprene fluxes from warm temperate seagrass communities dominated by specific seagrass species (Posidonia australis, Zostera muelleri and Halophila ovalis) in Wallis Lake, NSW, Australia, and from tropical seagrass communities (H. ovalis/Halodule uninervis mixed patches) on Lizard Island, QLD, Australia. P. australis and $Z$. muelleri were net isoprene sinks $\left(-0.6 \pm 0.1\right.$ and $-3.4 \pm 2.0 \mathrm{nmol} \mathrm{m}^{-2} \mathrm{~h}^{-1}$, respectively), whereas $H$. ovalis $\left(2.4 \pm 0.2 \mathrm{nmol} \mathrm{m}^{-2} \mathrm{~h}^{-1}\right)$ and mixed patches of $H$. ovalis/H. uninervis $(13.2 \pm$ $3.2 \mathrm{nmol} \mathrm{m}^{-2} \mathrm{~h}^{-1}$ ) were a net source of isoprene, indicating that seagrass communities can be both a source of and a sink for isoprene on a local scale depending on species. Overall, isoprene effluxes were more than 5 times higher on Lizard Island than in Wallis Lake, likely due to higher temperatures and prolonged sunlight on Lizard Island during the time of measurement. Wallis Lake and Lizard Island seagrass communities emit isoprene to the water column at an average rate of -0.3 and $8 \mathrm{mg} \mathrm{m}^{-2} \mathrm{yr}^{-1}$, respectively. Seagrass communities are a benthic source of iso-

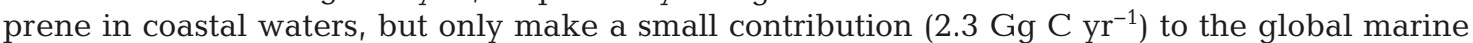
isoprene flux (11.6 $\left.\mathrm{Tg} \mathrm{C}_{\mathrm{r}^{-1}}\right)$.
\end{abstract}

KEY WORDS: BVOC - Biogenic volatile organic compound - Benthic incubations - Zostera . Halophila $\cdot$ Posidonia $\cdot$ Halodule

\section{INTRODUCTION}

Isoprene is one of the most important biogenic volatile organic compounds (BVOCs) on the planet, with emissions similar to those of methane in terms of carbon equivalents (Arneth et al. 2007, Menon et al. 2007). Isoprene is climatically important, with about $50 \%$ of secondary organic aerosol (SOA) formation in the atmosphere being due to isoprene photooxidation (Claeys et al. 2004, Liao et al. 2007). The hydroxy-driven oxidation of isoprene enhances particle growth and increases the capacity of aerosols to act as cloud condensation nuclei (CCN), causing a negative feedback loop in sea surface warming via the production

*Corresponding author: vhrebien@gmail.com of low-level shading clouds (Claeys et al. 2004, Meskhidze \& Nenes 2006). On the other hand, in terrestrial environments isoprene derived SOAs have the potential to influence cirrus cloud formation, potentially causing a net warming effect on global climate (Wolf et al. 2020). Isoprene has also been found to play a key role in the formation of tropospheric $\mathrm{O}_{3}$ in the presence of nitrous oxide $\left(\mathrm{NO}_{\mathrm{x}}\right)$ in polluted air (Fehsenfeld et al. 1992, Pierce et al. 1998, Li et al. 2007). As a result, isoprene not only contributes to $\mathrm{O}_{3}$ formation in the troposphere, leading to enhanced greenhouse effect, but also serves as a sink for oxidants in the marine boundary layer, which increases the residence time of greenhouse gases such as carbon

() The authors 2021. Open Access under Creative Commons by Attribution Licence. Use, distribution and reproduction are unrestricted. Authors and original publication must be credited. 
monoxide and methane, ultimately leading to global warming (Poisson et al. 2000). It remains unclear to what degree isoprene oxidation in the atmosphere contributes to warming and cooling on a global scale.

While isoprene has traditionally been considered a terrestrial gas, with $90 \%$ of the isoprene on Earth being released into the atmosphere by vegetation (Guenther et al. 1995), it is now well established that marine ecosystems also play an important role in isoprene production (Alcuna Alvarez et al. 2009, Arnold et al. 2009, Exton et al. 2013). In the open ocean, algal biomass drives isoprene production (Bonsang et al. 1992, Yokouchi et al. 1999), whereas in shallow, benthic marine habitats close to the coast, microbial communities are the major drivers of isoprene concentrations (Alcuna Alvarez et al. 2009, Shaw et al. 2010, Exton et al. 2012).

Isoprene production is strongly positively correlated with increases in temperature and light (Monson \& Fall 1989, Shaw et al. 2003, Broadgate et al. 2004), with isoprene emissions metabolically linked to photosynthesis (Monson et al. 1992, Guenther et al. 1995, Dani et al. 2017). Terrestrial studies have identified that the rate of isoprene emissions increases exponentially with temperature before reaching a clearly defined plateau at temperatures higher than $30^{\circ} \mathrm{C}$, demonstrating high sensitivity to temperatures between 25 and $30^{\circ} \mathrm{C}$ in terrestrial systems (Guenther et al. 1993, Pugh et al. 2013). Other drivers of isoprene production include abiotic stressors such as droughts and oxidative stress (Velikova et al. 2006, Sharkey et al. 2008, Loreto \& Schnitzler 2010). However, although nitrogen and phosphorus have been linked to an increase in productivity and growth in seagrass (Udy et al. 1999, Eyre \& Ferguson 2002, Eyre et al. 2011b), nutrient availability has yet to be definitively linked to isoprene production (Shaw et al. 2010), with varying results from previous studies (Evans 2009, Zindler et al. 2014).

To date, isoprene has been found in a variety of marine systems, with phytoplankton being one of the main marine isoprene producers in the ocean (Broadgate et al. 1997, Baker et al. 2000, Shaw et al. 2003). Isoprene production has also been measured from macroalgae (McKay et al. 1996, Broadgate et al. 2004), cyanobacteria (Lindberg et al. 2010), intertidal benthic microalgae (Exton et al. 2012), microbial communities (Alcuna Alvarez et al. 2009), coral-associated Symbiodinium (Exton et al. 2013), coral mucus (Swan et al. 2016), and coral reef carbonate sediments with microphytobenthos (MPB) (Hrebien et al. 2020b). Isoprene production has been found to be species dependent in seaweed (Broadgate et al. 2004) and pro- vides a source of carbon and energy to marine heterotrophic bacteria (Alcuna Alvarez et al. 2009).

Seagrasses are highly productive per unit area, constituting a key habitat for many marine organisms (Hughes et al. 2003). Seagrass beds are extremely complex ecosystems, with a great diversity and abundance of epiphytes composed mainly of microscopic algae (Moncreiff et al. 1992), and a benthic microflora composed mostly of pennate diatoms (Daehnick et al. 1992) and a rich microbial community, which combined are referred to as the seagrass MPB. All seagrass bed components contribute significantly to the primary production and autotrophic biomass of these communities (Borum et al. 1984, Moncreiff et al. 1992). Epiphytic algal biomass can equal or exceed that of the seagrass leaves (Moncreiff et al. 1992), ranging from 1 to $68 \%$ of the total leaf surface area (Borum et al. 1984), and can contribute up to a $56 \%$ increase in primary productivity within a seagrass bed (Morgan \& Kitting 1984). Since microalgae, diatoms, and bacteria can all produce isoprene, seagrass communities are expected to be a source of isoprene in the marine environment. However, there has been no measurement of benthic isoprene flux in seagrass communities to date.

In this study, we thus aimed to measure isoprene flux from seagrass communities dominated by 4 species (Zostera muelleri, Posidonia australis, Halophila ovalis, and Halodule uninervis) from both tropical (Lizard Island) and warm temperate (Wallis Lake) locations along the east Australian coast using benthic chamber deployments. Since temperature and, to a lesser extent, sunlight are known environmental drivers of isoprene production, we hypothesised that isoprene fluxes would be greater during the day than at night, with higher concentrations and fluxes at the tropical site than at the warm temperate site. Furthermore, shallow coastal marine habitats have the potential to endure dramatic temperature changes over the course of a day (Hancke \& Glud 2004), which will potentially lead to greater isoprene fluctuations. Because isoprene production has been detected in carbonate sands on Lizard Island (Hrebien et al. 2020b), it was expected that seagrass habitats within carbonate sediments would produce more isoprene as they become vegetated by seagrass and other isoprene producing organisms within the community. It was also expected that increased nutrients would lead to greater seagrass primary productivity and therefore increase isoprene production as a result. Given that seagrass beds constitute an interface between the terrestrial and marine world and $90 \%$ of isoprene emissions are 
sourced terrestrially, we hypothesised that seagrass communities make a significant contribution to global marine isoprene fluxes.

\section{MATERIALS AND METHODS}

\subsection{Study sites}

The first study was conducted from 13 to 20 March 2018 (early autumn) in Wallis Lake, Forster, NSW, Australia. This shallow, warm temperate, coastal lagoon is located approximately $360 \mathrm{~km}$ north of Sydney, NSW (Fig. 1) and has seawater temperatures ranging from 23 to $26^{\circ} \mathrm{C}$ in the summer and 18 to $20^{\circ} \mathrm{C}$ in the winter (BOM 2019). Wallis Lake has an open water area of $90 \mathrm{~km}^{2}$ with $33 \mathrm{~km}^{2}$ (37\%) seagrass coverage, a mean depth of $1.8 \mathrm{~m}$ (Eyre \& Maher 2010, Maher \& Eyre 2012, Eyre et al. 2016) with a semi-diurnal tidal range of $2 \mathrm{~m}$, and a net production of $55 \mathrm{~g} \mathrm{C} \mathrm{m}^{-2} \mathrm{yr}^{-1}$ (Maher \& Eyre 2011). A detailed description and map of the estuary is provided in Eyre \& Maher (2010). Sampling occurred within $50 \mathrm{~m}$ of the mainland shore along a concrete jetty behind

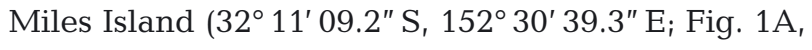
$\mathrm{D}, \mathrm{E})$. The sampling location was chosen due to the presence of adjacent seagrass communities, which were visually assessed as ecologically healthy (thick canopy cover, aboveground biomass visually rich in chlorophyll, evidence of new growth present, and presence of epiphytes). Measuring within the same location ensured that environmental conditions such as depth, light, and water movement varied minimally between species. This sheltered location also ensured optimal conditions for benthic chamber deployments. Consecutive chamber incubations were conducted over 4 communities containing densely vegetated areas of Zostera muelleri and Posidonia australis, lightly vegetated Halophila ovalis (Fig. 2A$\mathrm{C}$, respectively), and non-vegetated bare sediments (not pictured) (Dekker et al. 2003, Maher \& Eyre 2010). Three chamber replicates over each substrate type and one blank chamber were used for each incubation period. Z. muelleri have an aboveground biomass (mean $+\mathrm{SE}$ ) of $69.1 \pm 40.7 \mathrm{~g}$ dry wt $\mathrm{m}^{-2}$, belowground biomass of $38.2 \pm 24.0 \mathrm{~g}$ dry $\mathrm{wt} \mathrm{m}^{-2}$ and a sediment porosity of $0.66 \pm 0.01$ (vol:vol); $P$. australis have an aboveground biomass of $25.6 \pm 3.8 \mathrm{~g}$

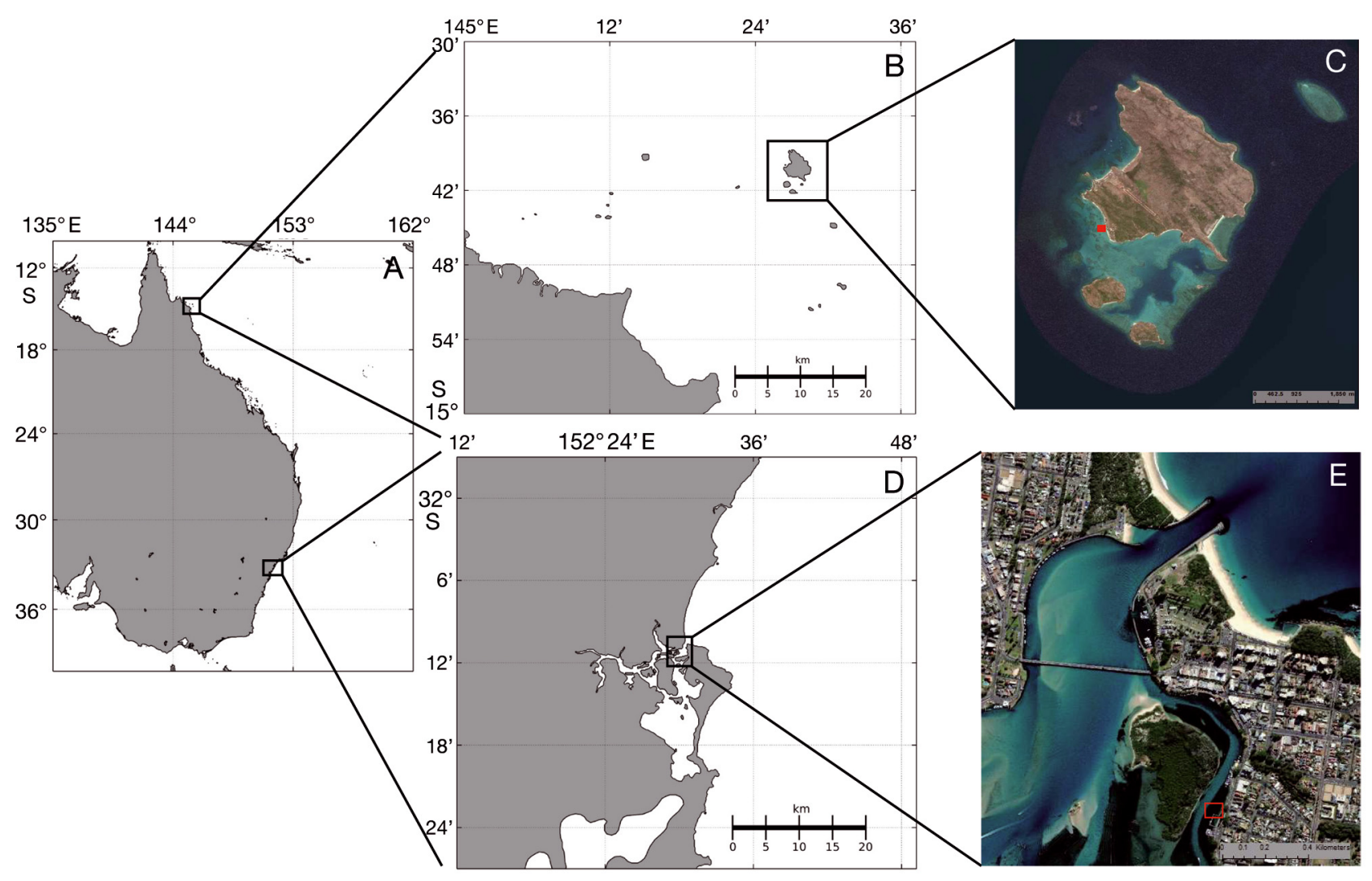

Fig. 1. Location of (A-C) Lizard Island, QLD (1440'36.6" S $\left.145^{\circ} 26^{\prime} 48.4^{\prime \prime} \mathrm{E}\right)$ and (A, D-E) Wallis Lake, NSW (32¹1'09.2" S, $\left.152^{\circ} 30^{\prime} 39.3^{\prime \prime} \mathrm{E}\right)$ in Australia. Study sites are indicated by red boxes in panels $\mathrm{C}$ and $\mathrm{E}$ 

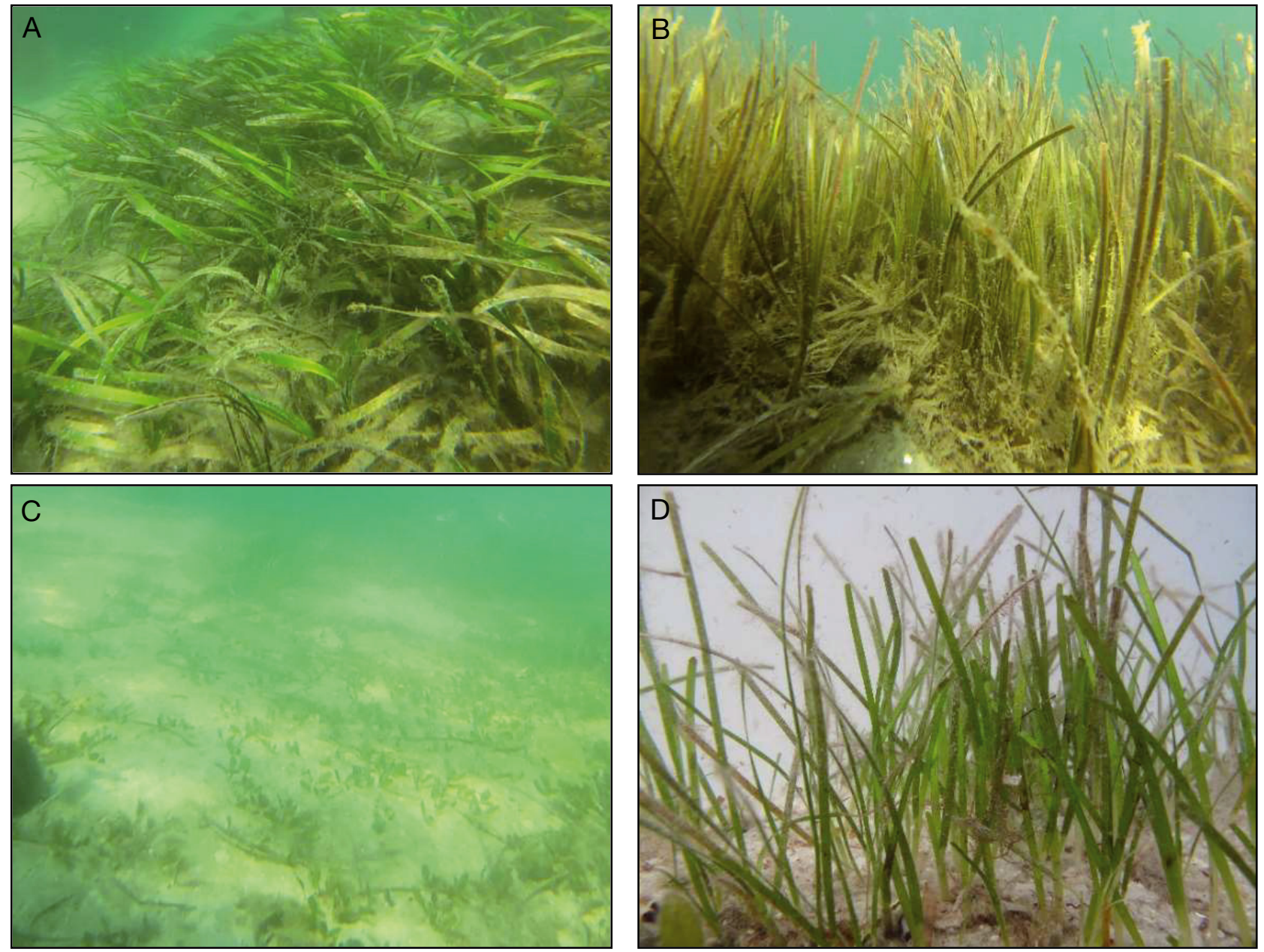

Fig. 2. Photos of seagrass beds used for benthic chamber deployments at (A-C) Wallis Lake, NSW and (D) Lizard Island, QLD. (A) Posidonia australis, (B) Zostera muelleri, (C) Halophila ovalis, and (D) mixed seagrass patch containing H. ovalis and Halodule uninervis

dry wt $\mathrm{m}^{-2}$, belowground biomass of $44.8 \pm 9.7 \mathrm{~g}$ dry wt $\mathrm{m}^{-2}$ and a sediment porosity of $0.63 \pm 0.06$ (vol:vol); and $H$. ovalis have an aboveground biomass of $2.4 \pm 0.1 \mathrm{~g}$ dry wt $\mathrm{m}^{-2}$, belowground biomass of 2.4 $\pm 0.3 \mathrm{~g}$ dry wt $\mathrm{m}^{-2}$ and a sediment porosity of $0.44 \pm$ 0.05 (vol:vol) (Camillini 2020). Biomass was measured in Wallis Lake at the time of this study.

All seagrass communities contained MPB and epiphytes and the bare sediments were covered in plant detritus and MPB (visual observation, Fig. 2).

The second study was conducted from 27 to 28 October 2018 (mid spring) within the Lizard Island Group, located $270 \mathrm{~km}$ north of Cairns, QLD, northern Great Barrier Reef, Australia (Fig. 1). Located in a tropical climate, with average seawater temperature of $24^{\circ} \mathrm{C}$ in the winter and $29^{\circ} \mathrm{C}$ in the summer (AIMS 2020), the Lizard Island National Park area covers $150 \mathrm{~km}^{2}$ with $0.18 \mathrm{~km}^{2}(1.2 \%)$ seagrass cov- erage (Saunders et al. 2015). Net production of C $\mathrm{m}^{-2} \mathrm{yr}^{-1}$ has not yet been determined. The Lizard Island Group (from here on referred to as Lizard Island) is situated between the coast and outer barrier reef on the mid continental shelf and is made up of 4 granite islands surrounded by fringing reefs. Together, these islands enclose a lagoon reaching up to $10 \mathrm{~m}$ in depth with a semi-diurnal tidal range of $3 \mathrm{~m}$. The lagoon is comprised of patch reefs and seagrass meadows mainly dominated by Halophila species $H$. ovalis, $H$. spinulosa, and $H$. decipiens, with partial coverage of Thalassia hemprichii and Halodule uninervis in shallow water (York et al. 2018). A single species habitat comparable to Wallis Lake was not available on Lizard Island at the time of sampling; therefore, sampling occurred within $50 \mathrm{~m}$ of shore off the southwestern side of the main Lizard Island $\left(14^{\circ} 40^{\prime} 36.6^{\prime \prime} \mathrm{S} \quad 145^{\circ} 26^{\prime} 48.4^{\prime \prime} \mathrm{E}\right.$; 
Fig. 1A-C) over a mixed seagrass patch containing $H$. ovalis (visually estimated as $40 \%$ of the patch measured) and $H$. uninervis (visually estimated as $60 \%$ of the patch measured). This location ensured a similar depth to that of Wallis Lake $(\sim 1.8 \mathrm{~m})$, which would provide similar conditions for light availability and water movement. Bare sediments adjacent to the seagrass were not measured due to permit and time constraints. Although plant detritus and MPB were present, this seagrass bed had relatively clean leaves (few epiphytes; Fig. 2D) in comparison with Wallis Lake (Fig. 2A-C). The sediments at the study site were fine carbonate sand and mud (McKenzie et al. 1997). Mixed patches of $H$. ovalis and $H$. uninervis on Lizard Island measured mid-spring had an aboveground biomass of 2.7 $\pm 2.8 \mathrm{~g}$ dry wt $\mathrm{m}^{-2}$ and belowground biomass of 6.5 $\pm 3.8 \mathrm{~g}$ dry wt $\mathrm{m}^{-2}$ (Saunders et al. 2015). Biomass and sediment porosity were not measured at the time of the study due to permit constraints.

Due to logistical constraints, sampling at similar times of the year was not possible; however, based on gross and net photosynthesis, intermediate seasons (spring and autumn) are more representative of averaged conditions than summer or winter, due to the higher respiration rates associated with summer temperatures (Dennison 1987). Since isoprene production is linked to photosynthesis, it is thus likely that intermediate seasons also represent average conditions in terms of isoprene emission.

\subsection{Chamber incubations}

Benthic isoprene fluxes were measured using 551 benthic flume-chambers (Eyre et al. 2011b, Camillini et al. 2021). Briefly, Perspex chambers with rounded ends, $680 \times 300 \times 300 \mathrm{~mm}$, and sediment surface area of $0.08 \mathrm{~m}^{2}$ were used in triplicate over seagrass beds or bare sediments (Fig. 3). Lateral flow across the seagrass was produced using an inflow bar positioned $1 \mathrm{~cm}$ from the lid on one end and a parallel outflow bar located $1 \mathrm{~cm}$ from the bottom of the chamber on the other side. A pump with regulated flow was attached to each inlet and outlet via $5 \mathrm{~m}$ hoses to produce a closed-circuit lateral flow at $51 \mathrm{~min}^{-1}$ across the seagrass community, mimicking in situ flows. The flow rate was chosen based on average current velocities within seagrass beds (Koch \& Gust 1999, Heiss et al. 2000). Chambers were placed over each of the seagrass communities or bare sediment sites in direct sunlight and left open for about $3 \mathrm{~h}$ with circulating flow to allow for the sediments and seawater profile to settle before sealing the chambers. Great care was taken not to step on the seagrass bed as the chambers were placed. Collapsible 201 bags were filled with in situ seawater at the time of chamber deployment and attached to the chambers to ensure that the same ambient seawater replaced water removed during sampling. Water was also collected from a blank bag to account for changes in water chemistry over time. One hour prior to sampling, chambers were sealed

Fig. 3. Schematic of the 551 benthic flume chambers used for benthic incubations. The remote power supply cable adjusts pump speed and controls lateral flow rate within chambers. Direction of flow is represented by blue arrows

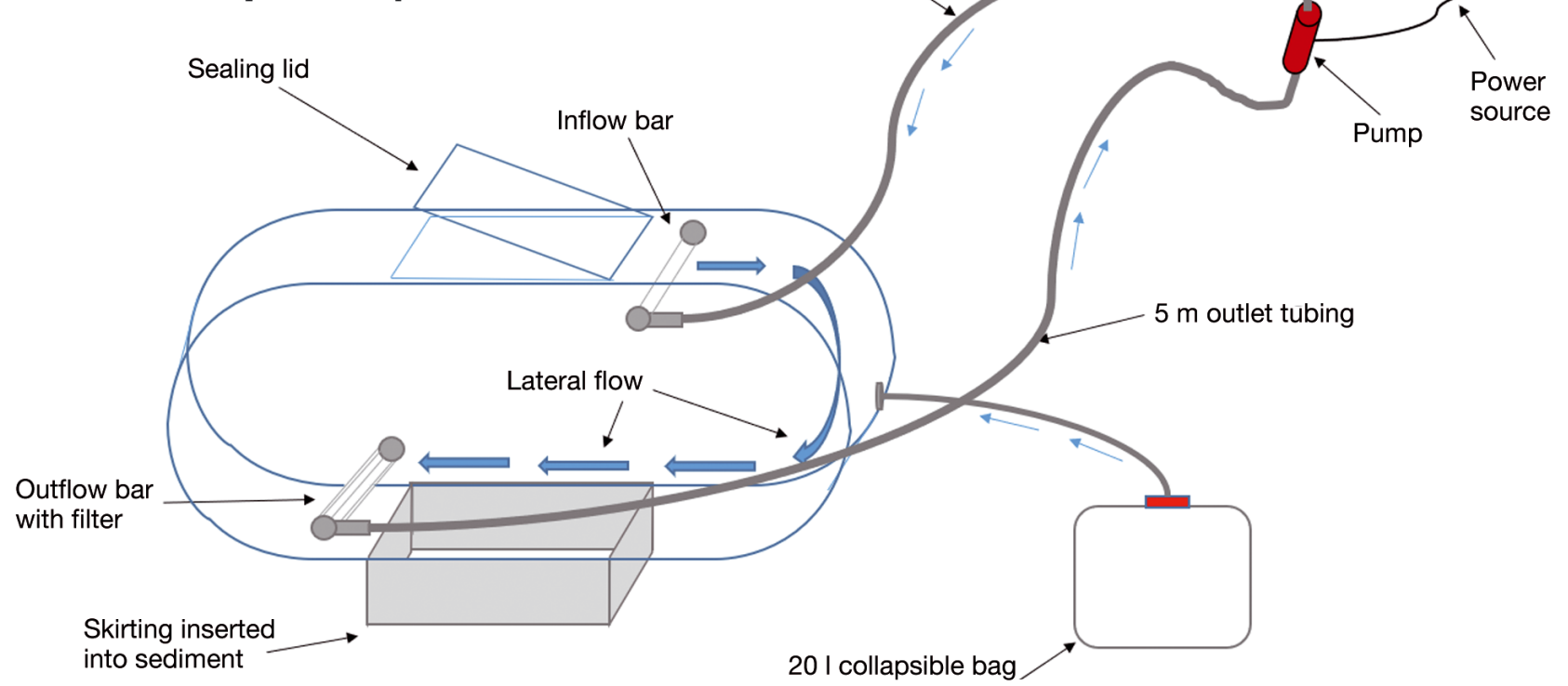


ensuring no bubbles were trapped inside the chambers. A blank chamber with a false bottom containing only seawater was used as an incubation control to remove production from phytoplankton and other isoprene producing organisms in the water column (Fig. A1 in the Appendix). Chambers were sampled every $4 \mathrm{~h}$ for $24 \mathrm{~h}$ over a diel cycle.

\subsection{Sampling}

Three chambers were deployed and sampled over each seagrass community and one blank chamber with a false bottom containing only water was deployed for each sampling period. Water samples were collected from each chamber by slowly filling $450 \mathrm{ml}$ amber glass Schott bottles to the top from a T-piece outlet placed upstream of the water pumps. Sub samples for all parameters and physico-chemical measurements were taken from the $450 \mathrm{ml}$ bottles. At Wallis Lake, all samples were preserved immediately following sampling; however, on Lizard Island, all sample bottles were transported to the Lizard Island Research Station in a water bath to ensure temperature was maintained at in situ conditions, and preserved within 45 min of collection.

Isoprene samples were collected by extracting $70 \mathrm{ml}$ of seawater from the $450 \mathrm{ml}$ sample bottles, which was syringed into $100 \mathrm{ml}$ amber glass sample bottles using a glass syringe mounted with Teflon tubing to ensure that sample bottles were filled from bottom up without bubbles. Sample bottles were immediately sealed with aluminium crimp top caps with Teflon septa (PTFE/S, Agilent Technologies). All isoprene samples were treated with $150 \mu \mathrm{lgCl}_{2}$ using a needle syringe and stored in the dark at $4^{\circ} \mathrm{C}$. Nutrient samples were collected from the $450 \mathrm{ml}$ bottles as follows: two $10 \mathrm{ml}$ nutrient samples were collected into $15 \mathrm{ml}$ centrifuge tubes after filtering using $0.45 \mu \mathrm{M}$ cellulose acetate syringe filters and frozen at $-20^{\circ} \mathrm{C}$ until analysis. Temperature $\left( \pm 0.1^{\circ} \mathrm{C}\right)$ and dissolved oxygen $\left(\mathrm{DO}_{i} \pm 0.01 \mathrm{mg} \mathrm{l}^{-1}\right)$ of each $450 \mathrm{ml}$ sample bottle were measured using a Hatch HQ 30d meter and Luminescent DO probe. Additionally, temperature $\left({ }^{\circ} \mathrm{C}\right)$ in Wallis Lake was also recorded using a Hydrolab HL4 Multiparameter Sonde (OTT HydroMet) every $15 \mathrm{~min}$ for the duration of each incubation. Photosynthetic active radiation (PAR) was recorded every $10 \mathrm{~min}$ within all chambers using HOBO loggers (UA-002-64) on Lizard Island (13 h light:11h dark cycle) and Wallis Lake (12 h light:12 h dark cycle). HOBO Lux units were calibrated using a Li-Cor-192 light meter to convert to $\mu \mathrm{mol}$ photons $\mathrm{m}^{-2} \mathrm{~s}^{-1}$ (Camillini 2020). Light data for $P$. australis is not available due to logger being shaded by the leaves within the chamber.

\subsection{Analytical methods}

\subsubsection{Isoprene and nutrient analysis}

Isoprene analysis was conducted within $30 \mathrm{~d}$ of collection by gas chromatography using cumulative headspace injections (Hrebien et al. 2020a). Briefly, isoprene samples were analysed on a gas chromatograph (GC; Agilent Technologies 6890N) coupled with a mass selective detector (MSD; Agilent Technologies 5973N) and a multipurpose sampler (MPS; Gerstel 2XL) set up with a $2.5 \mathrm{ml}$ syringe. The was operated in selective ion mode (SIM) mode with selected ion mass of 67,68 , and 53. Prior to measuring samples, a 6 point calibration ranging from 29 to $1429 \mathrm{pM}$ was performed onto the GC using isoprene standard (Sigma Aldrich; Ref 59240). The precision (coefficient of variation; CV) for this method is $2.6 \%$ for natural samples, accuracy based on recovery is $74-84 \%$, and detection limit is $15 \mathrm{pM}$.

Nutrient samples of ammonium $\left(\mathrm{NH}_{4}^{+}\right)$and phosphate $\left(\mathrm{PO}_{4}{ }^{3-}\right)$ were analysed using a Lachat flow injection analysis system; details of the methods, errors and detection limits are described in McKee et al. (2000).

\subsubsection{Benthic flux calculations}

Net flux for isoprene and nutrients $\left(\mathrm{nmol} \mathrm{m} \mathrm{m}^{-2} \mathrm{~h}^{-1}\right)$ was calculated using the following equation:

$$
F=\frac{\Delta S \times V}{A \times \Delta t}
$$

where $\Delta S$ is the change in solute concentration corrected for the addition of replacement water $\left(\mathrm{nmol} \mathrm{l} \mathrm{l}^{-1}\right)$ :

$$
\begin{aligned}
& S=[\text { initial concentration } \times \text { chamber volume }(1)]- \\
& [\text { volume withdrawn }(1) \times \text { blank concentration }]] /(2) \\
& \quad \text { [chamber volume }(1)-\text { volume withdrawn }(1)]
\end{aligned}
$$

and $v$ is the volume of the chamber (1), $A$ is the chamber surface area $\left(\mathrm{m}^{2}\right)$, and $\Delta t$ is the time elapsed between samples (h). Dark benthic fluxes were calculated using concentrations from dusk to dawn (19:00-06:00 $\mathrm{h}$ in Wallis Lake and 18:00-06:00 $\mathrm{h}$ on Lizard Island), while light benthic fluxes were calculated using concentrations from dawn to dusk (06:00-19:00 $\mathrm{h}$ in Wallis Lake and 06:00-18:00 $\mathrm{h}$ on Lizard Island) the following day. 


\subsubsection{Benthic metabolic rates}

Benthic metabolic rates for respiration (R), net primary productivity (NPP), gross primary productivity (GPP), and production to respiration ratio (P:R) were calculated based on DO fluxes $\left(\mathrm{mmol} \mathrm{O}_{2} \mathrm{~m}^{-2} \mathrm{~h}^{-1}\right)$, using the following equations (Eyre et al. 2011b):

$$
\begin{gathered}
\mathrm{R}=\text { Dark DO flux } \times-1 \\
\text { NPP }=\text { Light DO flux } \\
\text { GPP }=\text { NPP }+\mathrm{R} \\
\mathrm{P}: \mathrm{R}=\mathrm{GPP} \times \text { daylight } \mathrm{h} /(\mathrm{R} \times 24)
\end{gathered}
$$

\subsubsection{Statistical analysis}

Data was analysed using a univariate general linear model (GLM) with Bonferroni adjustment for multiple comparisons $(\alpha=0.05)$ to look at differences between species and locations (SPSS statistics 26). When referring to locations, Wallis Lake includes all species present $(P$. australis, $Z$. muelleri, and Halophila ovalis), while Lizard Island includes the single mixed patch measured (H. ovalis and Halodule uninervis). Prior to analysis, dependent variables (light, dark, and net isoprene fluxes; R, NPP, GPP, and P:R; and light, dark, and net nutrient fluxes) were tested for normality using a ShapiroWilks test and data that were not normally distributed $(p<0.05)$ were transformed. Isoprene and $\mathrm{R}$ were reciprocal $(1 / x)$ transformed and $\mathrm{PO}_{4}{ }^{3-}$ was square $\left(x^{2}\right)$ transformed. All other data $\left(\mathrm{NH}_{4}{ }^{+}, \mathrm{NPP}, \mathrm{GPP}, \mathrm{P}: \mathrm{R}\right)$ were normally distributed. Light and dark measurements were analysed using an unpaired $t$-test. Correlations between data were determined using a linear regression model.

\section{RESULTS}

\subsection{Temperature and light}

Temperature was significantly higher on Lizard Island (mid-spring) than in Wallis Lake (mid-fall) for all incubations (Table 1 ; unpaired $t$-test, $t_{\mathrm{df}}=$ $160, \mathrm{p}<0.01)$. Likewise, light was sig- nificantly greater on Lizard Island than in Wallis Lake during the Zostera muelleri incubation (Fig. $4 ; t_{\mathrm{df}}=$ $286, p=0.005$ ). Over $24 \mathrm{~h}$ there was no significant difference between light intensities during the Halophila ovalis incubation in Wallis Lake and the incubation on Lizard Island. However, PAR was significantly greater for the first $5 \mathrm{~h}$ of sunlight on Lizard Island $\left(t_{\mathrm{df}}=58, \mathrm{p}=\right.$ 0.03 ) than during the $H$. ovalis incubation in Wallis Lake and remained significantly higher between the hours of 14:00 and 16:00 ( $\left.t_{\mathrm{df}}=22, \mathrm{p}=0.01\right)$.

\subsection{Nutrients, $\mathrm{PO}_{4}{ }^{3-}$ and $\mathrm{NH}_{4}{ }^{+}$}

H. ovalis communities produced significantly more $\mathrm{PO}_{4}{ }^{3-}$ in the dark (mean \pm SE: $2.3 \pm 0.7 \mu \mathrm{mol} \mathrm{m}^{-2} \mathrm{~h}^{-1}$ ) than in the light $\left(-1.7 \pm 0.1 \mu \mathrm{mol} \mathrm{m}{ }^{-2} \mathrm{~h}^{-1}\right.$; Fig. $5 \mathrm{E}_{;} t_{\mathrm{df}}$ $=16, \mathrm{p}=0.01$ ) and $Z$. muelleri communities produced

Table 1. Sea surface temperature ranges $\left({ }^{\circ} \mathrm{C}\right)$ for each study location measured in situ and historically (Lizard Island: 2014-2020; Wallis Lake: 2014-2019)

\begin{tabular}{|lcccc|}
\hline Location & $\begin{array}{c}\text { Range } \\
\left( \pm 0.1^{\circ} \mathrm{C}\right)\end{array}$ & $\begin{array}{c}\text { Mean } \\
\left({ }^{\circ} \mathrm{C}\right)\end{array}$ & $\begin{array}{c}\text { Historical } \\
\text { range }\left({ }^{\circ} \mathrm{C}\right)\end{array}$ & Source \\
\hline $\begin{array}{l}\text { Wallis Lake, } \\
\text { NSW }\end{array}$ & $22.4-26.4$ & 24.5 & $\begin{array}{c}18-20 \text { (winter) } \\
\text { (BOM 2019) }\end{array}$ & (Bummer) \\
$\begin{array}{l}\text { Lizard Island, } \\
\text { QLD }\end{array}$ & $26.1-30.5$ & 27.9 & $\begin{array}{c}23-25 \text { (winter) } \\
29-31 \text { (summer) }\end{array}$ & (AIMS 2020) \\
\hline
\end{tabular}

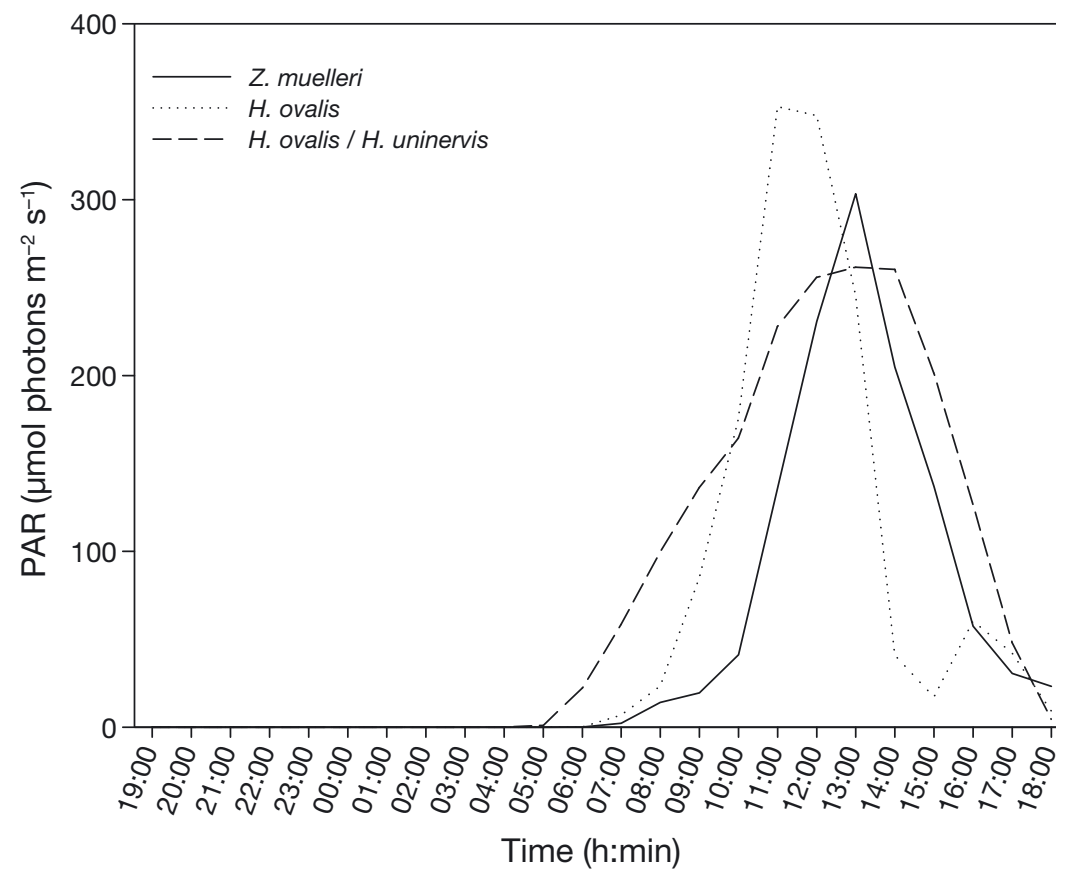

Fig. 4. PAR (photosynthetic active radiation; $\mu \mathrm{mol}$ photons $\mathrm{m}^{-2} \mathrm{~s}^{-1}$ ) for Zostera muelleri and Halophila ovalis in Wallis Lake and the mixed patch of $H$. ovalis and Halodule uninervis on Lizard Island 


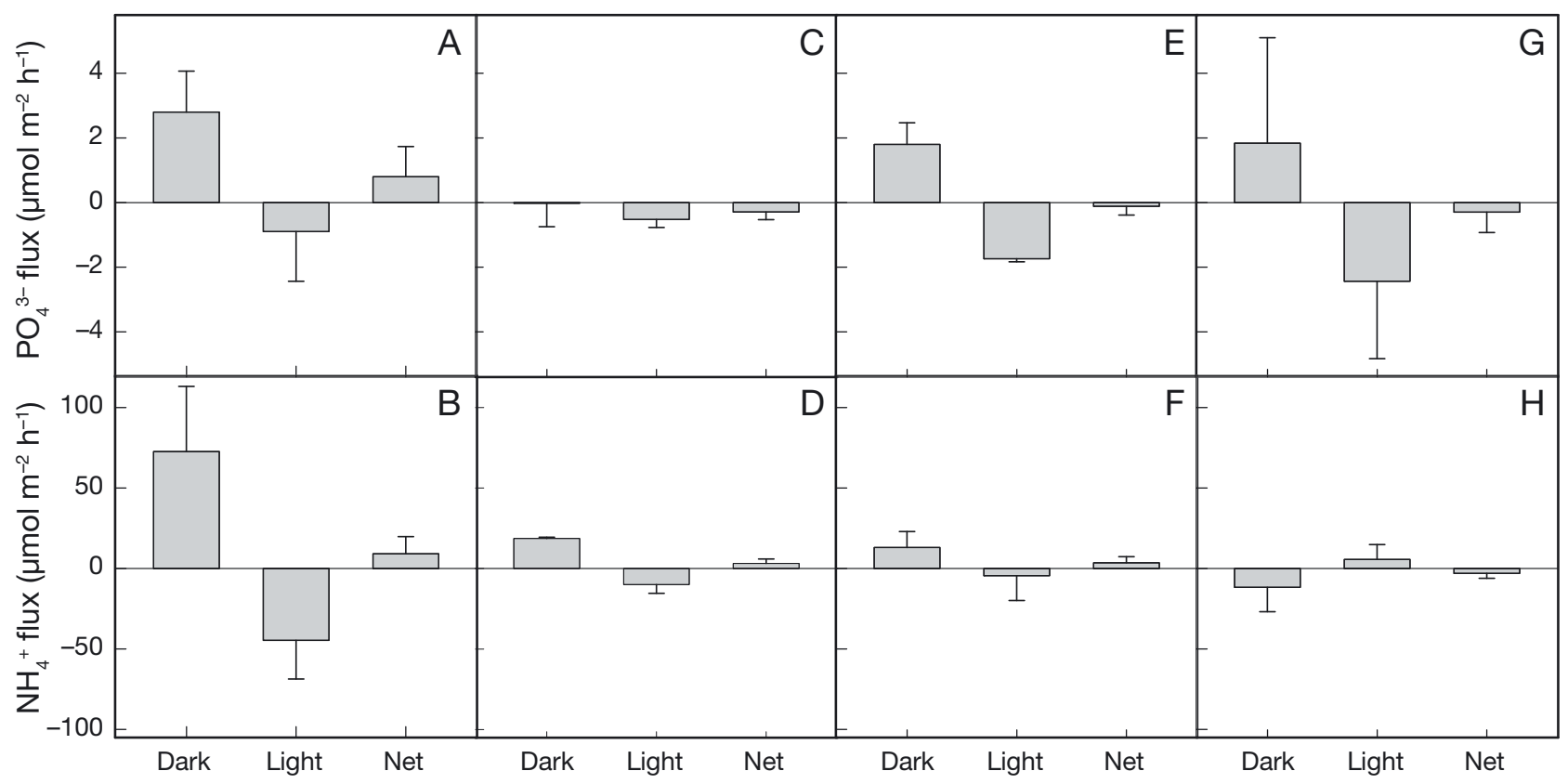

Fig. 5. Mean light, dark, and net $\mathrm{PO}_{4}{ }^{3-}$ and $\mathrm{NH}_{4}{ }^{+}$fluxes from $(\mathrm{A}, \mathrm{B})$ Posidonia australis, $(\mathrm{C}, \mathrm{D})$ Zostera muelleri, and $(\mathrm{E}, \mathrm{F})$ Halophila ovalis in Wallis Lake, and $(\mathrm{G}, \mathrm{H})$ a mixed seagrass patch of H. ovalis and Halodule uninervis on Lizard Island. Three chambers were deployed and sampled for each seagrass community. Error bars indicate SE

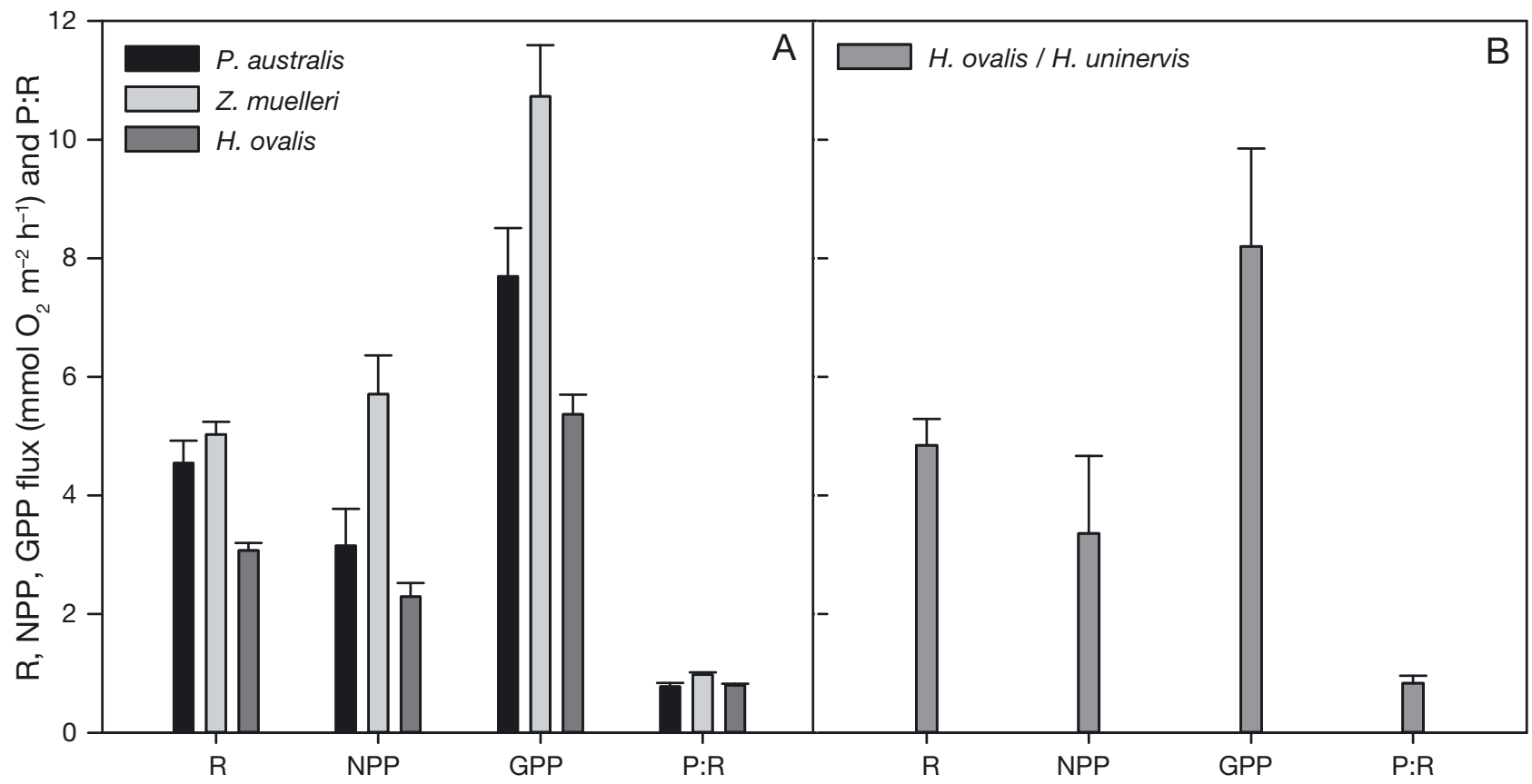

Fig. 6. Mean respiration (R), gross primary production (GPP), net primary production (NPP), and photosynthesis to respiration ratio (P:R) over (A) P. australis, Z. muelleri, and Halophila ovalis at Wallis Lake and (B) a mixed seagrass community containing H. ovalis and Halodule uninervis on Lizard Island. Three chambers were deployed and sampled for each seagrass community. Error bars indicate SE

significantly more $\mathrm{NH}_{4}{ }^{+}$in the dark $(18.7 \pm 0.7 \mu \mathrm{mol}$ $\left.\mathrm{m}^{-2} \mathrm{~h}^{-1}\right)$ than in the light $\left(-9.9 \pm 5.4 \mu \mathrm{mol} \mathrm{m}{ }^{-2} \mathrm{~h}^{-1}\right.$; Fig. $\left.6 \mathrm{D} ; t_{\mathrm{df}}=16, \mathrm{p}<0.01\right)$ in Wallis Lake. There were no significant differences in nutrient produc- tion between any other species in Wallis Lake or Lizard Island. Water column nutrient concentrations were on average $0.23 \mathrm{\mu mol} \mathrm{l}^{-1}$ for $\mathrm{PO}_{4}{ }^{3-}$ and $0.16 \mu \mathrm{mol} \mathrm{l}^{-1}$ for $\mathrm{NH}_{4}{ }^{+}$in Wallis Lake, and $0.05 \mu \mathrm{mol}$ 
$\mathrm{l}^{-1}$ for $\mathrm{PO}_{4}{ }^{3-}$ and $0.87 \mu \mathrm{mol} \mathrm{l}^{-1}$ for $\mathrm{NH}_{4}{ }^{+}$on Lizard Island (average of all open water samples taken during measurements).

\subsection{Respiration and photosynthesis}

Halophila ovalis beds had significantly lower $\mathrm{R}$ than $P$. australis and Z. muelleri in Wallis Lake and mixed seagrass $H$. ovalis and Halodule uninervis on Lizard Island (Fig. 6A,B; GLM, $F=7.75, \mathrm{p}=0.02, \mathrm{p}=$ $0.02, \mathrm{p}=0.03$, respectively). In Wallis Lake, GPP was also significantly greater in $Z$. muelleri than in $H$. ovalis communities (GLM, $F=4.57, \mathrm{p}=0.04$, respectively) and NPP was significantly greater in $Z$. muelleri beds than $H$. ovalis and $P$. australis beds (GLM, $F$ $=7.71, \mathrm{p}<0.01, \mathrm{p}=0.04)$. There was no significant difference between NPP on Lizard Island and any species in Wallis Lake and P:R was not significantly different between species or sites (Fig. 6A-C; GLM, $\mathrm{p}>0.05)$.

\subsection{Isoprene flux}

In Wallis Lake, there were light, dark, and net isoprene effluxes from the benthic community to the water column for Halophila ovalis and bare sediments, and light isoprene effluxes for $P$. aus- tralis and $Z$. muelleri. There were dark and net isoprene uptakes for $P$. australis and $Z$. muelleri (Fig. 7A). In Wallis Lake, Z. muelleri produced significantly more isoprene in the light (mean $( \pm \mathrm{SE})$ $\left.0.9 \pm 1.4 \mathrm{nmol} \mathrm{m} \mathrm{m}^{-2} \mathrm{~h}^{-1}\right)$ than in the dark $(-8.6 \pm$ $\left.3.0 \mathrm{nmol} \mathrm{m} \mathrm{m}^{-2} \mathrm{~h}^{-1} t_{\mathrm{df}}=4, \mathrm{p}=0.05\right)$ while $H$. ovalis produced significantly more isoprene in the dark $\left(5.6 \pm 0.6 \mathrm{nmol} \mathrm{m} \mathrm{m}^{-2} \mathrm{~h}^{-1}\right)$ than in the light $(0.5 \pm$ $\left.0.5 \mathrm{nmol} \mathrm{m}{ }^{-2} \mathrm{~h}^{-1} ; t_{\mathrm{df}}=4, \mathrm{p}<0.01\right)$. No other species showed significant differences between light and dark isoprene fluxes, nor were there any significant differences in isoprene flux between species in Wallis Lake. Bare sediments showed no change between light, dark or net isoprene flux (for all comparisons, $t_{\mathrm{df}}=4, \mathrm{p}=1.00$ ); furthermore, errors for all bare sediment measurements were greater than the flux, indicating they were not significantly different from zero.

On Lizard Island, there were light, dark, and net isoprene effluxes in the mixed seagrass beds of $H$. ovalis and Halodule uninervis (Fig. 7B). Lizard Island net isoprene fluxes (mean \pm SE) $13.2 \pm 3.2 \mathrm{nmol} \mathrm{m}^{-2} \mathrm{~h}^{-1}$ ) were significantly higher than all net isoprene fluxes across all species measured in Wallis Lake (GLM, $f=14.287$, $\mathrm{p}<0.01$ ). While not significant, the highest dark and light isoprene fluxes were observed on Lizard Island, ranging from -6.5 to $17.0 \mathrm{nmol} \mathrm{m}^{-2} \mathrm{~h}^{-1}$ (mean $\pm \mathrm{SE}$ ) 7.4 $\left.\pm 7.1 \mathrm{nmol} \mathrm{m}^{-2} \mathrm{~h}^{-1}\right)$ and 0.72 to $29.3 \mathrm{nmol} \mathrm{m}^{-2} \mathrm{~h}^{-1}(19.0$ $\pm 9.2 \mathrm{nmol} \mathrm{m}^{-2} \mathrm{~h}^{-1}$ ) respectively (Fig. 7B).

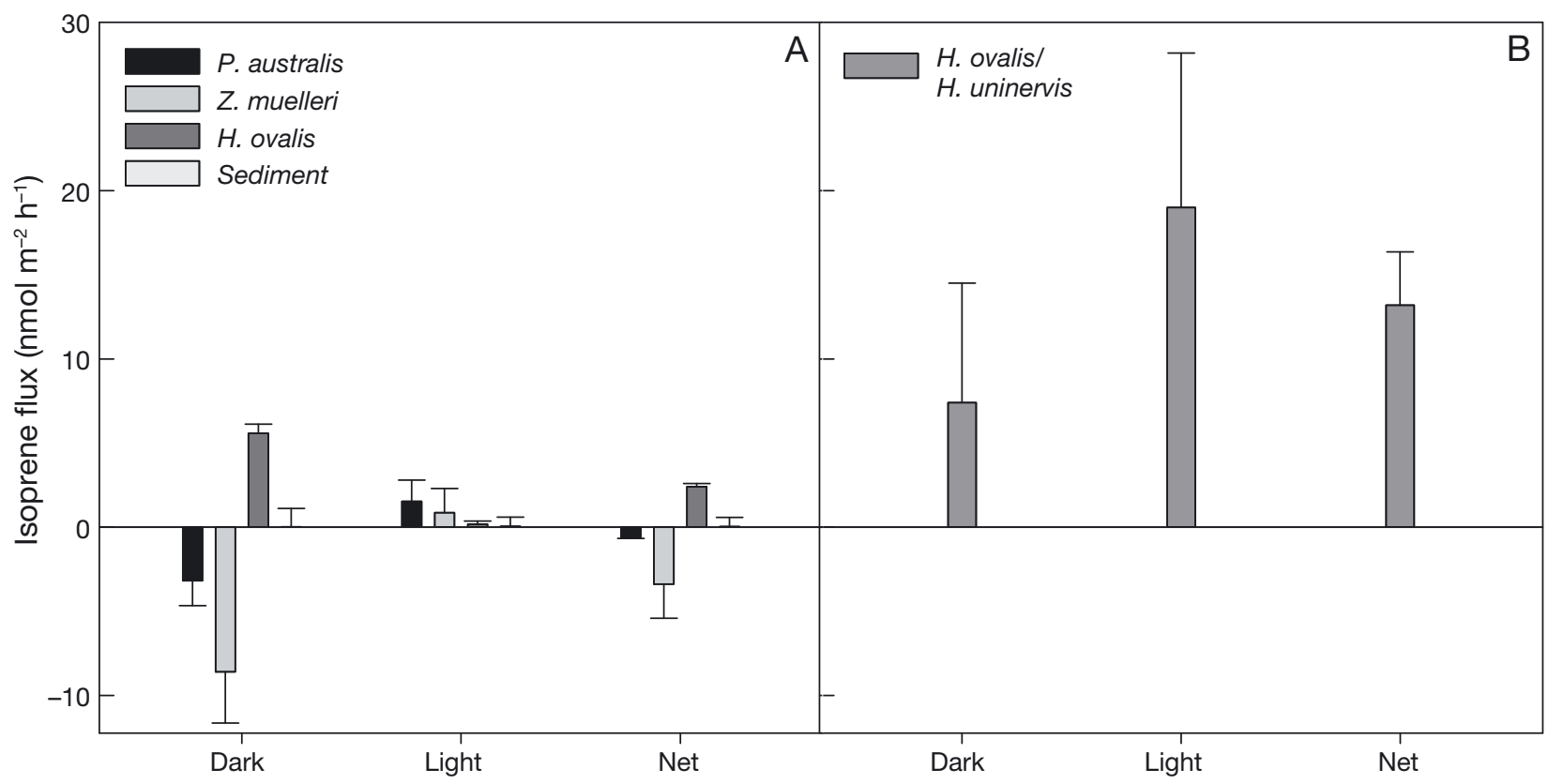

Fig. 7. Mean light, dark, and net isoprene fluxes over (A) 3 species of seagrass (P. australis, Z. muelleri and Halophila ovalis) and bare sediments in Wallis Lake, and (B) mixed seagrass bed containing H. ovalis and Halodule uninervis on Lizard Island.

Three chambers were deployed and sampled for each seagrass and bare sediment community. Error bars indicate SE 


\subsection{Significant correlations}

In Wallis Lake, isoprene fluxes negatively correlated with $\mathrm{PO}_{4}{ }^{3-}$ and $\mathrm{NH}_{4}{ }^{+}$in $\mathrm{P}$. australis beds (Fig. $8 \mathrm{~A}, \mathrm{~B}_{;} \mathrm{PO}_{4}{ }^{3-}: \mathrm{R}^{2}=0.455, \mathrm{p}=0.046, \mathrm{n}=9$ and $\mathrm{NH}_{4}^{+}: \mathrm{R}^{2}=0.771, \mathrm{p}=0.009, \mathrm{n}=7$ ). Isoprene fluxes positively correlated with $\mathrm{PO}_{4}{ }^{3-}$ in Halophila ovalis patches in Wallis Lake (Fig. $8 C_{i} \mathrm{R}^{2}=0.852, \mathrm{p}<0.001$, $\mathrm{n}=9$ ); however, isoprene fluxes negatively correlated with $\mathrm{PO}_{4}{ }^{3-}$ in mixed seagrass containing $\mathrm{H}$. ovalis and Halodule uninervis on Lizard Island (Fig. $8 \mathrm{D} ; \mathrm{R}^{2}=0.543, \mathrm{p}=0.024, \mathrm{n}=9$ ). There were no significant correlations for $Z$. muelleri.
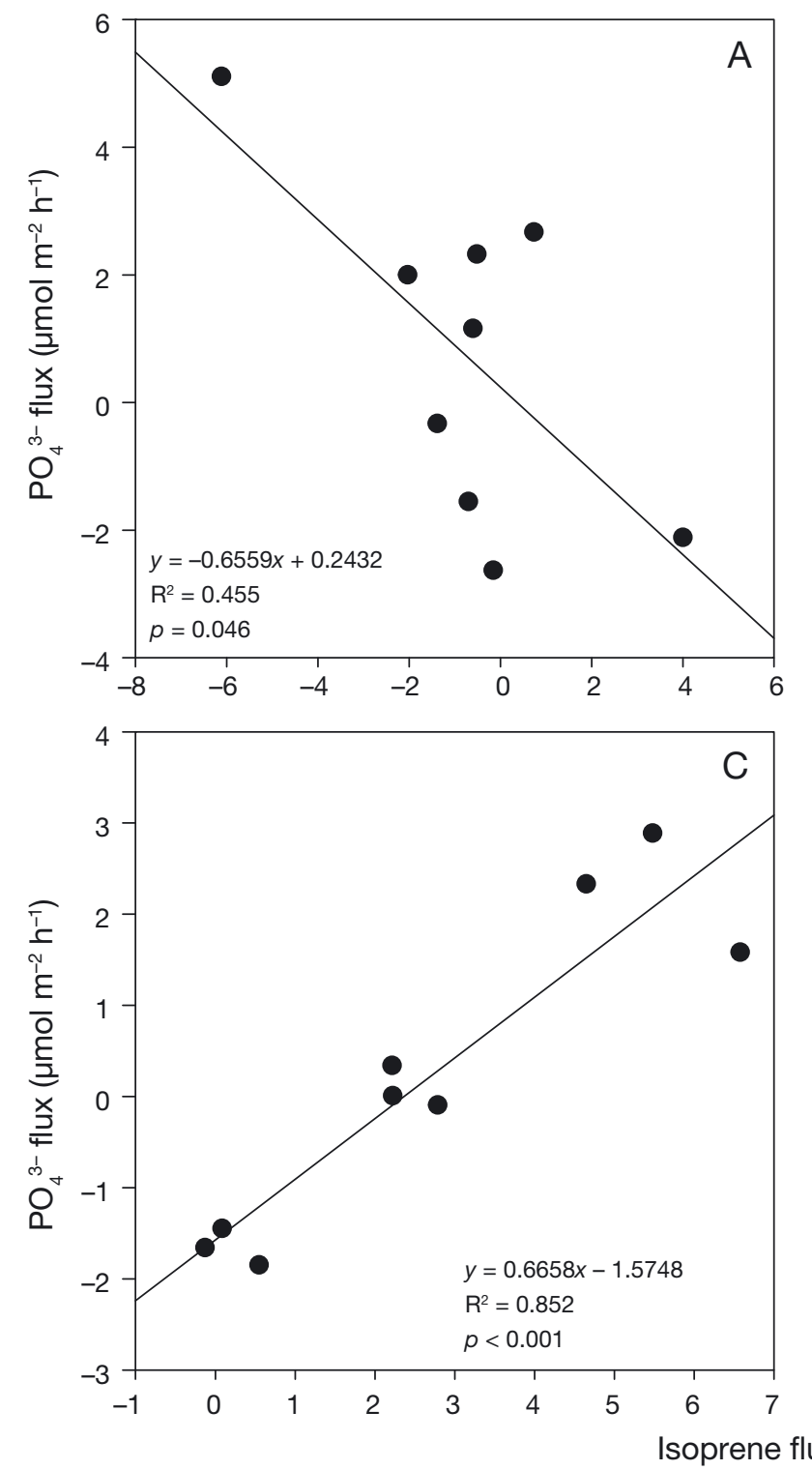

Fig. 8. Significant correlations between parameters measured over (A,B) P. australis and (C) Halophila ovalis (n = 7-9, varies due to missing data) at Wallis Lake and (D) mixed seagrass beds containing H. ovalis and Halodule uninervis on Lizard Island $(\mathrm{n}=9)$

\section{DISCUSSION}

\subsection{Seagrass habitats are both a source of and sink for isoprene in the water column}

This study is the first to report benthic isoprene fluxes from seagrass communities. Seagrass communities from both tropical (Lizard Island) and warm temperate (Wallis Lake) regions were a source of and sink for isoprene in the marine environment, with this pattern being highly species-specific. For instance, Halophila ovalis and Halodule uninervis were net sources of isoprene in the water column, whereas an
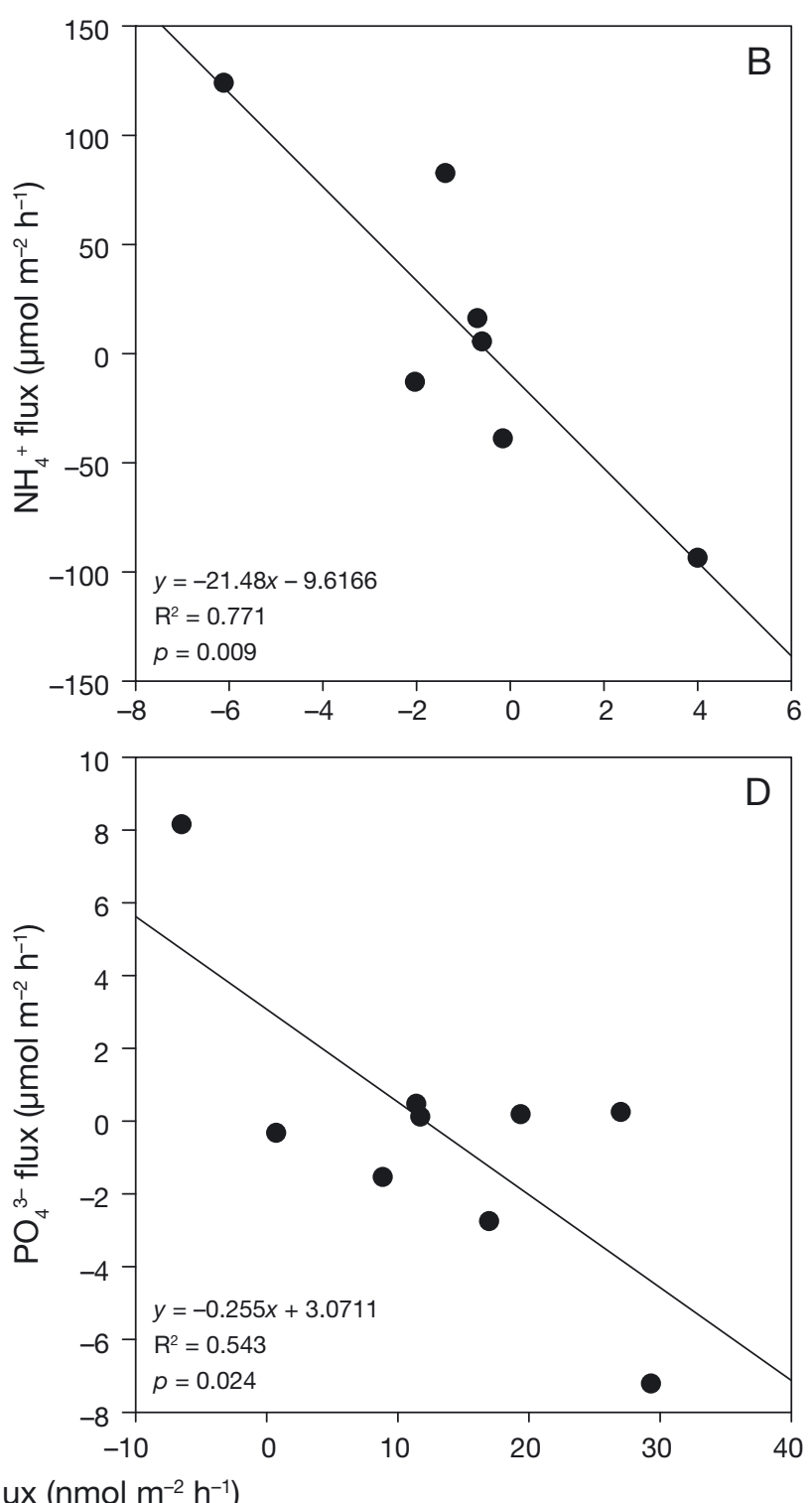
Table 2. Benthic isoprene fluxes

\begin{tabular}{|llcl|}
\hline Source & Locations & Net flux $\left(\mathrm{nmol} \mathrm{m} \mathrm{h}^{-1}\right.$ ) & Reference \\
\hline Sediments & Wales, UK & 0.0004 & (Bravo-Linares \& Mudge 2007) \\
Sediments (MPB) & Essex, UK & $8.2 \pm 1.2$ & (Exton et al. 2012) \\
Sediments (MPB) & Heron Island, QLD & $10.0 \pm 1.1$ & (Hrebien et al. 2020b) \\
Sediments (MPB) & Lizard Island, QLD & $3.9 \pm 0.9$ & Current study \\
Sediments & Wallis Lake, NSW & $0.0 \pm 0.6$ & \\
Seagrass & Wallis Lake, NSW & $-0.6 \pm 0.1$ & \\
P. australis & Wallis Lake, NSW & $-3.4 \pm 2.0$ & \\
Z. muelleri & Wallis Lake, NSW & $2.4 \pm 0.2$ & \\
H. ovalis & Lizard Island, QLD & $13.2 \pm 3.2$ & \\
H. ovalis/H. uninervis & & & \\
\hline
\end{tabular}

uptake of isoprene was measured in $Z$. muelleri and $P$. australis beds. Isoprene fluxes from mixed patches containing $H$. ovalis and $H$. uninervis on Lizard Island were higher than previous benthic fluxes from sediments containing MPB on Heron Island and Lizard Island (Australia) as well as in Essex (UK) (Table 2). This was expected, as seagrass has a much higher biomass than non-vegetated carbonate sands or sediments dominated by MPB. Similar to sandy sediments measured in Wales (UK), non-vegetated sediment incubations in Wallis Lake had very low to no flux (Table 2), indicating that benthic isoprene fluxes likely exclusively come from segrasscommunities, which include above- and belowground seagrass biomass as well as epiphytes and MPB, although $H$. ovalis effluxes in Wallis Lake were still quite low. While benthic incubations provide the advantage of in situ measurements, they do not allow separate components within seagrass beds to be isolated. This highlights the need for additional studies to determine individual isoprene production and consumption from each component within seagrass communities.

\subsection{The drivers of isoprene production in seagrass communities are species-specific}

Isoprene fluxes were typically greater during the day than at night in both temperate (Wallis Lake) and tropical (Lizard Island) habitats, suggesting that most of the isoprene production in seagrass communities is driven by photosynthesis. This is consistent with the negative correlation between isoprene and both $\mathrm{NH}_{4}{ }^{+}$ and $\mathrm{PO}_{4}{ }^{3-}$ in $P$. australis and in mixed seagrass patches containing Halophila ovalis and Halodule uninervis (Fig. 5), which indicate $\mathrm{NH}_{4}{ }^{+}$and $\mathrm{PO}_{4}{ }^{3-}$ uptakes through seagrass community productivity (Eyre \& Ferguson 2002, Eyre et al. 2011a). A number of studies have shown an increase in isoprene produc- tion due to the influence of photosynthesis (Guenther et al. 1995) as well as temperature and light (Monson \& Fall 1989, Broadgate et al. 2004). In Wallis Lake, $Z$. muelleri and $P$. australis had a significantly greater GPP and R than H. ovalis (Fig. 6), which, combined with an uptake of isoprene at night in both $Z$. muelleri and $P$. australis, suggests an absence of isoprene production in the dark combined with isoprene uptake by either the seagrass or associated microbial community (Alcuna Alvarez et al. 2009).

On Lizard Island, although isoprene efflux from mixed seagrass patches containing $H$. ovalis and $H$. uninervis was higher during the day (mean \pm SE 19.0 $\left.\pm 9.2 \mathrm{nmol} \mathrm{m}^{-2} \mathrm{~h}^{-1}\right)$ than at night $\left(7.4 \pm 7.1 \mathrm{nmol} \mathrm{m}^{-2}\right.$ $\mathrm{h}^{-1}$ ), an efflux of isoprene was still observed at night, suggesting isoprene production via a different pathway than photosynthesis. Benthic bacteria can both produce and consume isoprene, although this is species dependent (Shaw et al. 2003, Alcuna Alvarez et al. 2009). Isoprene production by terrestrial bacteria has been demonstrated at night (Kuzma et al. 1995) due to the breakdown of stored carbohydrates in plant cells in the absence of light (Lerdau et al. 1997). Furthermore, unicellular green algae produce isoprene in the dark via heterotrophic use of exogenous glucose at the same rate as they produce isoprene in the light via photosynthesis (Dani et al. 2020). These mechanisms could be occurring in seagrass habitats. A similar pattern was also observed in MPB (Exton et al. 2012, Hrebien et al. 2020b), cyanobacterial cultures (Shaw et al. 2003), and macro-algae (Broadgate et al. 2004), suggesting that seagrass habitats behave in a similar way to other benthic systems.

In Wallis Lake, $H$. ovalis exhibited higher isoprene efflux at night (mean $\pm \mathrm{SE} 5.6 \pm 0.6 \mathrm{nmol} \mathrm{m}^{-2} \mathrm{~h}^{-1}$ ) than during the day $\left(0.2 \pm 0.2 \mathrm{nmol} \mathrm{m}^{-2} \mathrm{~h}^{-1}\right)$. This might reflect the uptake of isoprene by bacteria during the day, although this is more likely to occur at night (Alvarez et al. 2009). Due to its morphology, it is also 
possible that $H$. ovalis can become $\mathrm{O}_{2}$ stressed, and an $\mathrm{O}_{2}$ surplus from productivity during the day would diffuse from seagrass leaves through the roots and rhizomes, oxygenating and enriching the sediments (Pedersen et al. 1998, Greve et al. 2003, Rasmusson 2015). This phenomenon, known as radial $\mathrm{O}_{2}$ loss (ROL), could lead to an increase in isoprene production from MPB at night. While ROL occurs in other species, it is directly related to the available light to leaf ratio, with the zone of ROL in $H$. ovalis extending more than twice as far as that in $Z$. muelleri (Martin et al. 2019). Furthermore, the higher isoprene efflux at night compared to other species could be due to the microbial community associated with $H$. ovalis, which could be more productive and contain more heterotrophic organisms that produce isoprene at night than that associated with $P$. australis or $Z$. muelleri (Dani et al. 2020). However, the abundance and composition of bacteria communities in these seagrass beds has not been measured in this study and thus should be the focus of future investigations.

$H$. ovalis had significantly lower isoprene flux during the day than other seagrass species, which could be linked to a difference in productivity as GPP, NPP, and $\mathrm{R}$ were significantly lower in $H$. ovalis than in $Z$. muelleri (Fig. 6). Halophila spp. are extremely sensitive to UV-B irradiation, which can inhibit photosynthesis (Halldal 1964, Drew 1979, Foyer et al. 1994). For example, $H$. ovalis is highly physiologically responsive when exposed to moderate irradiances (500 $\mu \mathrm{mol}$ photons $\mathrm{m}^{-2} \mathrm{~s}^{-1}$ ) and oxidative stress, triggering photoprotective responses such as non-photochemical quenching and clumping of chloroplasts, which would limit the amount of light being absorbed (Phandee \& Buapet 2018). Halodule spp., on the other hand, have a higher physiological tolerance for UV-B irradiance stress, with photo-repair mechanisms to reduce photosynthetic inhibition (Trocine et al. 1981). The low-relief growth form of Halophila spp. usually enables shading from other, larger species as well as epiphytes and detritus (Trocine et al. 1981). However, the study site at Wallis Lake did not have shade from other species and individual leaves were more exposed to light. While maximum irradiance only reached $353 \mu \mathrm{mol}$ photons $\mathrm{m}^{-2} \mathrm{~s}^{-1}$, it is still possible that isoprene produced during the day was immediately photooxidised due to higher light penetration throughout the water column, with UV-B associated stress leading to a decrease in productivity (Foyer et al. 1994, Phandee \& Buapet 2018) and potentially a decline in isoprene production. Therefore, it is possible that the difference in day primary production rates between Wallis Lake and Lizard
Island (Fig. 6) is linked to the presence of both $H$. uninervis and $H$. ovalis, with one being responsible for production during the day and the other at night, respectively. In terrestrial plants, oxidative stress can increase isoprene production under increased levels of UV-B radiation (Loreto \& Velikova 2001); however, the physiological function of isoprene in seagrass and other marine systems is not yet understood. For example, while isoprene is released as a thermoregulator in terrestrial plants, this is not the case in phytoplankton in the open ocean (Shaw et al. 2003).

Isoprene production in seagrass communities was species-specific, which has also been demonstrated in seaweed (Broadgate et al. 2004) as well as in phytoplankton (Milne et al. 1995) and bacteria (Alvarez et al. 2009). Temperate seagrass communities dominated by $P$. australis and $Z$. muelleri were found to be net sinks for isoprene. While both species emit isoprene during the day, increased uptake at night resulted in a net uptake over the diel cycle. In Wallis Lake, P. australis was twice as productive as $Z$. muelleri during the day (mean \pm SE $1.5 \pm 1.3 \mathrm{nmol} \mathrm{m}^{-2} \mathrm{~h}^{-1}$ and $0.9 \pm$ $1.4 \mathrm{nmol} \mathrm{m}{ }^{-2} \mathrm{~h}^{-1}$ respectively), which is expected since it is proportionally nearly 3 times the size of $Z$. muelleri (aboveground biomass: mean \pm SE $69.1 \pm$ $40.7 \mathrm{~g}$ dry wt $\mathrm{m}^{-2}$ and $25.6 \pm 3.8 \mathrm{~g}$ dry wt $\mathrm{m}^{-2}$, respectively) (Camillini 2020). Furthermore, isoprene uptake in $Z$. muelleri was more than twice the uptake of $P$. australis at night (mean $\pm \mathrm{SE}-8.6 \pm 3.0 \mathrm{nmol} \mathrm{m}^{-2} \mathrm{~h}^{-1}$ and $-3.2 \pm 1.5 \mathrm{nmol} \mathrm{m}^{-2} \mathrm{~h}^{-1}$ respectively). Compared to $H$. ovalis or $H$. uninervis, $P$. australis and $Z$. muelleri have larger leaves, which constitute a greater surface area for macrophytes, microalgae and bacteria to grow. Visual observations suggest that both $P$. australis (Fig. 2A) and Z. muelleri (Fig. 2B) had a substantially greater macrophyte community than $H$. ovalis (Fig. 2C) and the mixed patch of $H$. ovalis and $H$. uninervis (Fig. 2D), which had cleaner leaves. Therefore, it is likely that the higher isoprene uptake in $P$. australis and $Z$. muelleri is due to the presence of macrophytes and associated microbial community (Broadgate et al. 2004, Alvarez et al. 2009). In contrast, $H$. ovalis emitted isoprene during light and dark periods in both locations, indicating that seagrass communities dominated by $H$. ovalis can be considered a net source of isoprene in the water column.

\subsection{Isoprene fluxes from tropical and warm temperate regions across different species}

Isoprene fluxes were significantly greater on Lizard Island (tropical habitat) than in any species or 
sediment in Wallis Lake (temperate zone) (Table 2). Since isoprene production is driven by light and temperature, with isoprene production generally increasing exponentially with temperature (Guenther et al. 1995, Pugh et al. 2013), tropical habitats likely have higher isoprene emissions (Exton et al. 2015). Although the study in Wallis Lake was conducted in mid-March (early autumn), temperatures ranged from 22.4 to $26.4^{\circ} \mathrm{C}$, with the average temperature $\left(24.5^{\circ} \mathrm{C}\right)$ falling within the summer temperature range $\left(23-26^{\circ} \mathrm{C}\right)$. On the other hand, the study on Lizard Island was conducted in late October (mid-spring), with measured temperatures ranging from 26.1 to $30.5^{\circ} \mathrm{C}$, with the average temperature $\left(27.9^{\circ} \mathrm{C}\right)$ falling just under the summer temperature range $\left(29-31^{\circ} \mathrm{C}\right)$. The optimal temperature for growth and productivity in temperate seagrass species ranges from 11.5 to $26^{\circ} \mathrm{C}$, whereas for subtropical and tropical species optimal temperatures range from 23 to $32^{\circ} \mathrm{C}$ (Lee et al. 2007). Temperatures in Wallis Lake were within the thermal optima for temperate seagrasses $P$. australis and $Z$. muelleri, although both species represented a sink for isoprene. On the other hand, tropical/subtropical species Halophila ovalis was within optimal temperature range for tropical seagrass growth and productivity at both locations, with Wallis Lake and Lizard Island representing the lower and upper ends of the range, respectively. Since isoprene emissions are metabolically linked to photosynthesis (Monson et al. 1992, Guenther et al. 1995, Dani et al. 2017), overall higher temperature and increased hours of light (Fig. 6) in the tropics were likely the main factors influencing isoprene production in this study. Based on average temperature ranges at each location and the optimum range for seagrass growth and productivity, it was predicted that isoprene production would be higher on Lizard Island for the tropical and subtropical species $H$. ovalis and $H$. uninervis, with the annual temperature range $\left(23-31^{\circ} \mathrm{C}\right.$; Table 1) being close to the temperature optima for these species $\left(23-32^{\circ} \mathrm{C}\right)$. Wallis Lake is likely to have Halodule uninervis with the annual temperature range $\left(23-31^{\circ} \mathrm{C}\right.$; Table 1$)$ being close to the temperature optima for these species $\left(23-32^{\circ} \mathrm{C}\right)$. Wallis Lake is likely to have lower isoprene production, with maximum temperatures only reaching the lower end of the optimal scale and most of the year falling below optimal temperatures for $\mathrm{H}$. ovalis $\left(18-26^{\circ} \mathrm{C}_{i}\right.$ Table 1$)$. It is thus possible that during the winter no isoprene is produced at all in $H$. ovalis.

Seasonal variability in seagrass usually increases productivity during spring and summer and decreases productivity in fall and winter as temperature significantly affects photosynthesis and respiration, which are considered as major growth factors in seagrass (Lee \& Dunton 1996, Lee et al. 2005). In this study, it is likely that Wallis Lake seagrass productivity was low due to lower temperatures, while on Lizard Island, seagrass productivity was high due to increasing temperatures, with our measurements reflecting this seasonal pattern. As mentioned earlier, this study is likely representative of yearly average seagrass production; however, additional studies measuring seasonal maximums and minimums in isoprene production need to be conducted to understand the true contribution of these seagrass communities to local and global isoprene budgets.

$H$. ovalis in Wallis Lake and the mixed $H$. ovalis/H. uninervis on Lizard Island showed similar trends, with isoprene production in both light and dark. However, the isoprene fluxes from these species were significantly higher on Lizard Island than in Wallis Lake, with isoprene effluxes measuring nearly 20 times greater in the light and 2 times greater in the dark, resulting in a 10 times greater net efflux. While temperature and light are drivers of isoprene production in the tropics, it was not feasible to measure $H$. uninervis on its own, which makes it difficult to determine whether there could also be a species-specific element causing higher isoprene fluxes on Lizard Island.

The aboveground biomass for $H$. ovalis (mean $\pm \mathrm{SE}$ $2.4 \pm 0.1 \mathrm{~g}$ dry wt $\mathrm{m}^{-2}$ ) in Wallis Lake and for the mixed seagrass $H$. ovalis and $H$. uninervis $(2.7 \pm 2.8 \mathrm{~g}$ dry wt $\mathrm{m}^{-2}$ ) on Lizard Island were similar; however, the belowground biomass on Lizard Island (6.5 \pm $3.8 \mathrm{~g}$ dry wt $\mathrm{m}^{-2}$ ) was almost 3 times greater than that in Wallis Lake $\left(2.4 \pm 0.3 \mathrm{~g}\right.$ dry wt $\left.\mathrm{m}^{-2}\right)$. To build the root system necessary for the sediment composition, assimilated carbon needs to be allocated from aboveground biomass to belowground biomass via photosynthesis (Hemminga 1998). Since roots and rhizomes need nutrient uptake for growth and colonisation, nutrient availability is also a factor to consider when comparing belowground biomass. In Wallis Lake, resources for growth are likely to be more readily available within the water column, whereas on Lizard Island, nutrients likely come from porewater where uptake by belowground biomass is key, although further research is necessary to confirm this.

\subsection{Seagrass as a source of isoprene to the water column}

In Wallis Lake, $P$. australis covers $4.4 \%$ of the total lake area, Z. muelleri $21.2 \%$ and Halophila ovalis 
$5.27 \%$ (Eyre \& Maher 2010). Using a total lake area of $90 \mathrm{~km}^{2}$ and a total net isoprene flux rate of $-0.3 \mathrm{mg}$ $\mathrm{m}^{-2} \mathrm{yr}^{-1}$ for all species, seagrass communities in Wallis Lake were found to be a sink for isoprene, with a total uptake of $-0.008 \mathrm{~T} \mathrm{C} \mathrm{yr}^{-1}$. While $H$. ovalis was found to emit small amounts of isoprene at $1 \mathrm{mg} \mathrm{m}^{-2}$ $\mathrm{yr}^{-1}\left(0.006 \mathrm{~T} \mathrm{C} \mathrm{yr}^{-1}\right)$, its $5 \%$ coverage within the lake was not enough to counteract the lack of isoprene production from $P$. australis $\left(0 \mathrm{mg} \mathrm{m}^{-2} \mathrm{yr}^{-1},-0.001 \mathrm{~T}\right.$

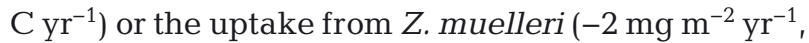
$-0.034 \mathrm{~T} \mathrm{C} \mathrm{yr}^{-1}$ ).

On Lizard Island, $H$. ovalis and Halodule uninervis constitute $0.33 \%$ of the total reef area (Saunders et al. 2015). Using a total reef area of $150 \mathrm{~km}^{2}$ for Lizard Island, and a net isoprene flux rate of $8 \mathrm{mg} \mathrm{m}^{-2} \mathrm{yr}^{-1}$, we estimated that mixed seagrass communities of $H$. ovalis and $H$. uninervis emit $0.003 \mathrm{~T} \mathrm{C} \mathrm{yr}^{-1}$ from Lizard Island. While net isoprene flux rates were more than 10 times greater on Lizard Island (net: $13.21 \pm 3.2 \mathrm{nmol} \mathrm{m}^{-2} \mathrm{~h}^{-1}$ ) than for all species in Wallis Lake (combined net: $-0.53 \pm 0.8 \mathrm{nmol} \mathrm{m}{ }^{-2} \mathrm{~h}^{-1}$ ), the small seagrass coverage on Lizard Island for these 2 species makes their contribution insignificant, even in comparison to carbonate sediments on Lizard Island, which emit $0.09 \mathrm{~T} \mathrm{C} \mathrm{yr}^{-1}$ of isoprene (Hrebien et al. 2020b).

Using a global area of $350000 \mathrm{~km}^{2}$ for seagrass (Duarte 2017), and an average annual isoprene flux rate for Wallis Lake and Lizard Island of $8 \mathrm{mg} \mathrm{m}^{-2}$ $\mathrm{yr}^{-1}$ (min: 2, max: 13), the global isoprene flux from these seagrass species is estimated to range from

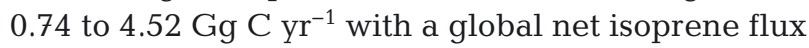

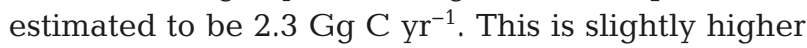
than the estimated global isoprene flux from coral

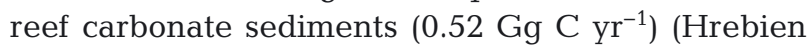
et al. 2020b); however, it is still much lower than estimated global isoprene flux from phytoplankton (0.66 Tg C yr ${ }^{-1}$ ) (Conte et al. 2020), and only a small contribution to the global marine isoprene flux of 11.6 Tg C yr-1 (Luo \& Yu 2010).

While we acknowledge the uncertainties of extrapolating from only 2 locations and a few seagrass species, it is still worthwhile to put our findings into a global context. As it stands, this 'back of the envelope' estimate is not meant to be an absolute value, as it contains a percentage of error due to lack of seasonal sampling, does not take into account fluctuations of light and temperature throughout the year, and is constrained by a small sample size. However, it helps to see how the snapshot measured in this study compares to global estimates and other studies, and indicates that isoprene sources and sinks from seagrass are perhaps more important on a local scale than on a global scale. Additional studies across a wider range of seagrass communities dominated by different seagrass species in both tropical and temperate climates and across different seasons capturing the minimum and maximum temperature range over the year are required to obtain a more accurate estimate of how seagrass contributes to the global isoprene budget. Furthermore, additional studies on epiphytes and microbial communities are needed to determine the contribution of each component of seagrass communities. Nevertheless, this study has provided seagrass community isoprene emissions in coastal waters and identified new knowledge gaps to be explored.

Acknowledgements. We acknowledge the Lizard Island Research Station staff for their continued support and use of facilities. We thank Nicola Camillini (Southern Cross University) for his assistance with equipment preparation and fieldwork at Wallis Lake, Tyler Cyronak and Alyssa Finlay (Scripps Oceanography/University of California, San Diego) for assistance with fieldwork on Lizard Island, and Catherine Collier for photos. This work was supported by the ARC Discovery grant awarded to B.D.E. (DP150102092) under the Great Barrier Reef Marine Park permit G16/38438.1.

\section{LITERATURE CITED}

AIMS (Australian Institute of Marine Science) (2020) Sea water temperature logger data at Lizard Island, Great Barrier Reef from 27 Oct 1995 to 05 Dec 2018. https:// apps.aims.gov.au/metadata/view/b8fc8578-fef9-43fa9483-222ade016c2b (Accessed 15 Jan 2021)

Alcuna Alvarez L, Exton DA, Timmis KN, Suggett DJ, McGenity TJ (2009) Characterization of marine isoprene-degrading communities. Environ Microbiol 11: 3280-3291

Arneth A, Schurgers G, Hickler T, Miller P (2008) Effects of species composition, land surface cover, $\mathrm{CO}_{2}$ concentration and climate on isoprene emissions from European forests. Plant Biol 10:150-162

Arnold S, Spracklen D, Williams J, Yassaa N and others (2009) Evaluation of the global oceanic isoprene source and its impacts on marine organic carbon aerosol. Atmos Chem Phys 9:1253-1262

Baker A, Turner S, Broadgate W, Thompson A and others (2000) Distribution and sea-air fluxes of biogenic trace gases in the eastern Atlantic Ocean. Global Biogeochem Cycles 14:871-886

BOM (Bureau of Meteorology) (2019) Sea temperature \& currents. w00231. BOM, Melbourne

Bonsang B, Polle C, Lambert G (1992) Evidence for marine production of isoprene. Geophys Res Lett 19:1129-1132

* Borum J, Kaas H, Wium-Andersen S (1984) Biomass variation and autotrophic production of an epiphyte-macrophyte community in a coastal Danish area: II. Epiphyte species composition, biomass and production. Ophelia 23:165-179

*Bavo-Linares CM, Mudge SM (2007) Analysis of volatile organic compounds (VOCs) in sediments using in situ SPME sampling. J Environ Monit 9:411-418 
Broadgate WJ, Liss PS, Penkett SA (1997) Seasonal emissions of isoprene and other reactive hydrocarbon gases from the ocean. Geophys Res Lett 24:2675-2678

Broadgate W, Malin G, Küpper F, Thompson A, Liss P (2004) Isoprene and other non-methane hydrocarbons from seaweeds: a source of reactive hydrocarbons to the atmosphere. Mar Chem 88:61-73

Camillini N (2020) Carbon and nitrogen cycling in seagrass ecosystems. PhD thesis, Southern Cross University and University of Southern Denmark, Lismore and Odense

Camillini N, Attard KM, Eyre BD, Glud RNJ (2021) Resolving community metabolism of eelgrass Zostera marina meadows by benthic flume-chambers and eddy covariance in dynamic coastal environments. Mar Ecol Prog Ser 661:97-114

Claeys M, Graham B, Vas G, Wang W and others (2004) Formation of secondary organic aerosols through photooxidation of isoprene. Science 303:1173-1176

Conte L, Szopa S, Aumont O, Gros V, Bopp L (2020) Sources and sinks of isoprene in the global open ocean: simulated patterns and emissions to the atmosphere. J Geophys Res, C, Oceans 125:e2019JC015946

Daehnick A, Sullivan M, Moncreiff C (1992) Primary production of the sand microflora in seagrass beds of Mississippi Sound. Bot Mar 35:131-140

*Dani KGS, Benavides AMS, Michelozzi M, Peluso G, Torzillo G, Loreto F (2017) Relationship between isoprene emission and photosynthesis in diatoms, and its implications for global marine isoprene estimates. Mar Chem 189:17-24

Dani KGS, Torzillo G, Michelozzi M, Baraldi R, Loreto F (2020) Isoprene emission in darkness by a facultative heterotrophic green alga. Front Plant Sci 11:598786

Dekker AG, Anstee JM, Brando VE (2003) Seagrass change assessment using satellite data for Wallis Lake, NSW. Technical Report 13/03 April 2013. CSIRO Land and Water, Canberra

Dennison WC (1987) Effects of light on seagrass photosynthesis, growth and depth distribution. Aquat Bot 27: 15-26

Drew EA (1979) Physiological aspects of primary production in seagrasses. Aquat Bot 7:139-150

Duarte CM (2017) Reviews and syntheses: Hidden forests, the role of vegetated coastal habitats in the ocean carbon budget. Biogeosciences 14:301-310

Evans T (2009) Biological volatile organic compounds (BVOCs) emissions from the planktonic diatom Thalassiosira pseudonana. MSc thesis, Stony Brook University, NY

Exton DA, Suggett DJ, Steinke M, McGenity TJ (2012) Spatial and temporal variability of biogenic isoprene emissions from a temperate estuary. Global Biogeochem Cycles 26:GB2012

Exton DA, Suggett DJ, McGenity TJ, Steinke M (2013) Chlorophyll-normalized isoprene production in laboratory cultures of marine microalgae and implications for global models. Limnol Oceanogr 58:1301-1311

Exton DA, McGenity TJ, Steinke M, Smith DJ, Suggett DJ (2015) Uncovering the volatile nature of tropical coastal marine ecosystems in a changing world. Glob Change Biol 21:1383-1394

Eyre BD, Ferguson AJ (2002) Comparison of carbon production and decomposition, benthic nutrient fluxes and denitrification in seagrass, phytoplankton, benthic microalgaeand macroalgae-dominated warm-temperate Australian lagoons. Mar Ecol Prog Ser 229:43-59
Eyre BD, Maher DT (2010) Structure and function of warm temperate east Australian coastal lagoons: implications for natural and anthropogenic changes. In: Kennish MJ, Paerl HW (eds) Coastal lagoons: critical habitats of environmental change. CRC Press, Boca Raton, FL, p 457-481

* Eyre BD, Ferguson AJ, Webb A, Maher D, Oakes JM (2011a) Denitrification, N-fixation and nitrogen and phosphorus fluxes in different benthic habitats and their contribution to the nitrogen and phosphorus budgets of a shallow oligotrophic sub-tropical coastal system (southern Moreton Bay, Australia). Biogeochemistry 102:111-133

*Eyre BD, Ferguson AJ, Webb A, Maher D, Oakes JM (2011b) Metabolism of different benthic habitats and their contribution to the carbon budget of a shallow oligotrophic sub-tropical coastal system (southern Moreton Bay, Australia). Biogeochemistry 102:87-110

* Eyre BD, Maher DT, Sanders C (2016) The contribution of denitrification and burial to the nitrogen budgets of three geomorphically distinct Australian estuaries: importance of seagrass habitats. Limnol Oceanogr 61:1144-1156

Fehsenfeld F, Calvert J, Fall R, Goldan P and others (1992) Emissions of volatile organic compounds from vegetation and the implications for atmospheric chemistry. Global Biogeochem Cycles 6:389-430

* Foyer CH, Lelandais M, Kunert KJ (1994) Photooxidative stress in plants. Physiol Plant 92:696-717

* Greve TM, Borum J, Pedersen O (2003) Meristematic oxygen variability in eelgrass (Zostera marina). Limnol Oceanogr 48:210-216

Guenther AB, Zimmerman PR, Harley PC, Monson RK, Fall $\mathrm{R}$ (1993) Isoprene and monoterpene emission rate variability: model evaluations and sensitivity analyses. J Geophys Res D Atmospheres 98:12609-12617

* Guenther A, Hewitt CN, Erickson D, Fall R and others (1995) A global model of natural volatile organic compound emissions. J Geophys Res D Atmospheres 100:8873-8892

* Halldal P (1964) Ultraviolet action spectra of photosynthesis and photosynthetic inhibition in a green and a red alga. Physiol Plant 17:414-421

* Hancke K, Glud RN (2004) Temperature effects on respiration and photosynthesis in three diatom-dominated benthic communities. Aquat Microb Ecol 37:265-281

Heiss WM, Smith AM, Probert PK (2000) Influence of the small intertidal seagrass Zostera novazelandica on linear water flow and sediment texture. Mar Freshw Res 34:689-694

*Hemminga M (1998) The root/rhizome system of seagrasses: an asset and a burden. J Sea Res 39:183-196

*Hrebien V, Deschaseaux E, Eickhoff W, Swan HB, Eyre BD (2020a) Quantification of isoprene in coastal ecosystems by gas chromatography-mass spectrometry using cumulative headspace injections. Limnol Oceanogr Methods 18:374-382

Hrebien V, Deschaseaux E, Eyre B (2020b) Isoprene flux from permeable carbonate sediments on the Great Barrier Reef. Mar Chem 225:103856

*Hughes TP, Baird AH, Bellwood DR, Card M and others (2003) Climate change, human impacts, and the resilience of coral reefs. Science 301:929-933

* Koch EW, Gust G (1999) Water flow in tide-and wavedominated beds of the seagrass Thalassia testudinum. Mar Ecol Prog Ser 184:63-72

Kuzma J, Nemecek-Marshall M, Pollock WH, Fall R (1995) Bacteria produce the volatile hydrocarbon isoprene. Curr Microbiol 30:97-103 
Lee KS, Dunton KH (1996) Production and carbon reserve dynamics of the seagrass Thalassia testudinum in Corpus Christi Bay, Texas, USA. Mar Ecol Prog Ser 143:201-210

Lee KS, Park SR, Kim JB (2005) Production dynamics of the eelgrass, Zostera marina in two bay systems on the south coast of the Korean peninsula. Mar Biol 147:1091-1108

Lee KS, Park SR, Kim YK (2007) Effects of irradiance, temperature, and nutrients on growth dynamics of seagrasses: a review. J Exp Mar Biol Ecol 350:144-175

Lerdau M, Guenther A, Monson R (1997) Plant production and emission of volatile organic compounds. Bioscience 47:373-383

Li G, Zhang R, Fan J, Tie X (2007) Impacts of biogenic emissions on photochemical ozone production in Houston, Texas. J Geophys Res D Atmospheres 112:D10309

Liao H, Henze DK, Seinfeld JH, Wu S, Mickley LJ (2007) Biogenic secondary organic aerosol over the United States: comparison of climatological simulations with observations. J Geophys Res D Atmospheres 112:D06201

Lindberg P, Park S, Melis A (2010) Engineering a platform for photosynthetic isoprene production in cyanobacteria, using Synechocystis as the model organism. Metab Eng 12:70-79

Loreto F, Schnitzler JP (2010) Abiotic stresses and induced BVOCs. Trends Plant Sci 15:154-166

Loreto F, Velikova V (2001) Isoprene produced by leaves protects the photosynthetic apparatus against ozone damage, quenches ozone products, and reduces lipid peroxidation of cellular membranes. Plant Physiol 127: 1781-1787

Luo G, Yu F (2010) A numerical evaluation of global oceanic emissions of $\alpha$-pinene and isoprene. Atmos Chem Phys 10:2007-2015

Maher DT, Eyre BD (2010) Benthic fluxes of dissolved organic carbon in three temperate Australian estuaries: implications for global estimates of benthic DOC fluxes. J Geophys Res Biogeosci 115:G04039

Maher D, Eyre BD (2011) Benthic carbon metabolism in southeast Australian estuaries: habitat importance, driving forces, and application of artificial neural network models. Mar Ecol Prog Ser 439:97-115

Maher DT, Eyre BD (2012) Carbon budgets for three autotrophic Australian estuaries: implications for global estimates of the coastal air-water CO2 flux. Global Biogeochem Cycles 26:GB1032

Martin BC, Bougoure J, Ryan MH, Bennett WW and others (2019) Oxygen loss from seagrass roots coincides with colonisation of sulphide-oxidising cable bacteria and reduces sulphide stress. ISME J 13:707-719

McKay W, Turner M, Jones B, Halliwell C (1996) Emissions of hydrocarbons from marine phytoplankton-some results from controlled laboratory experiments. Atmos Environ 30:2583-2593

McKee L, Eyre B, Hossain SJ (2000) Intra- and interannual export of nitrogen and phosphorus in the subtropical Richmond River catchment, Australia. Hydrol Processes 14:1787-1809

McKenzie L, Long WL, Bradshaw E (1997) Distribution of seagrasses in the Lizard Island group: a reconnaissance survey, October 1995. CRC Reef Research Technical Report, 14. CRC Reef Research Centre, Townsville

Menon S, Denman KL, Brasseur G, Chidthaisong A and others (2007) Couplings between changes in the climate system and biogeochemistry. Lawrence Berkeley National Lab, Berkeley, CA
Meskhidze N, Nenes A (2006) Phytoplankton and cloudiness in the Southern Ocean. Science 314:1419-1423

Milne PJ, Riemer DD, Zika RG, Brand LE (1995) Measurement of vertical distribution of isoprene in surface seawater, its chemical fate, and its emission from several phytoplankton monocultures. Mar Chem 48:237-244

*Moncreiff CA, Sullivan MJ, Daehnick AE (1992) Primary production dynamics in seagrass beds of Mississippi Sound: the contributions of seagrass, epiphytic algae, sand microflora, and phytoplankton. Mar Ecol Prog Ser 87:161-171

*Monson RK, Fall R (1989) Isoprene emission from aspen leaves: influence of environment and relation to photosynthesis and photorespiration. Plant Physiol 90:267-274

* Monson RK, Jaeger CH, Adams WW, Driggers EM, Silver GM, Fall R (1992) Relationships among isoprene emission rate, photosynthesis, and isoprene synthase activity as influenced by temperature. Plant Physiol 98: $1175-1180$

* Morgan MD, Kitting CL (1984) Productivity and utilization of the seagrass Halodule wrightii and its attached epiphytes. Limnol Oceanogr 29:1066-1076

* Pedersen O, Borum J, Duarte CM, Fortes MD (1998) Oxygen dynamics in the rhizosphere of Cymodocea rotundata. Mar Ecol Prog Ser 169:283-288

Phandee S, Buapet P (2018) Photosynthetic and antioxidant responses of the tropical intertidal seagrasses Halophila ovalis and Thalassia hemprichii to moderate and high irradiances. Bot Mar 61:247-256

* Pierce T, Geron C, Bender L, Dennis R, Tonnesen G, Guenther A (1998) Influence of increased isoprene emissions on regional ozone modeling. J Geophys Res, D, Atmospheres 103:25611-25629

* Poisson N, Kanakidou M, Crutzen PJ (2000) Impact of nonmethane hydrocarbons on tropospheric chemistry and the oxidizing power of the global troposphere: 3-dimensional modelling results. J Atmos Chem 36:157-230

*Pugh T, Ashworth K, Wild O, Hewitt C (2013) Effects of the spatial resolution of climate data on estimates of biogenic isoprene emissions. Atmos Environ 70:1-6

Rasmusson LM (2015) Seagrass respiration: an assessment of oxygen consumption patterns of temperate marine macrophytes. PhD thesis, Stockholm University

* Saunders MI, Bayraktarov E, Roelfsema CM, Leon JX and others (2015) Spatial and temporal variability of seagrass at Lizard Island, Great Barrier Reef. Bot Mar 58:35-49

Sharkey TD, Wiberley AE, Donohue AR (2008) Isoprene emission from plants: why and how. Ann Bot (Lond) 101:5-18

Shaw SL, Chisholm SW, Prinn RG (2003) Isoprene production by Prochlorococcus, a marine cyanobacterium, and other phytoplankton. Mar Chem 80:227-245

* Shaw SL, Gantt B, Meskhidze N (2010) Production and emissions of marine isoprene and monoterpenes: a review. Adv Meteorol 2010:1-24

* Swan HB, Crough RW, Vaattovaara P, Jones GB and others (2016) Dimethyl sulfide and other biogenic volatile organic compound emissions from branching coral and reef seawater: potential sources of secondary aerosol over the Great Barrier Reef. J Atmos Chem 73: 303-328

Trocine RP, Rice JD, Wells GN (1981) Inhibition of seagrass photosynthesis by ultraviolet-B radiation. Plant Physiol 68:74-81

*Udy JW, Dennison WC, Long WJL, McKenzie LJ (1999) 
Responses of seagrass to nutrients in the Great Barrier Reef, Australia. Mar Ecol Prog Ser 185:257-271

Velikova V, Loreto F, Tsonev T, Brilli F, Edreva A (2006) Isoprene prevents the negative consequences of high temperature stress in Platanus orientalis leaves. Funct Plant Biol 33:931-940

Wolf MJ, Zhang Y, Zawadowicz MA, Goodell M and others (2020) A biogenic secondary organic aerosol source of cirrus ice nucleating particles. Nat Commun 11:4834

Yokouchi Y, Li HJ, Machida T, Aoki S, Akimoto H (1999) Iso- prene in the marine boundary layer (southeast Asian Sea, eastern Indian Ocean, and Southern Ocean): comparison with dimethyl sulfide and bromoform. J Geophys Res, D, Atmospheres 104:8067-8076

*York PH, Macreadie PI, Rasheed MA (2018) Blue carbon stocks of Great Barrier Reef deep-water seagrasses. Biol Lett 14:20180529

Z Zindler C, Marandino CA, Bange HW, Schütte F, Saltzman ES (2014) Nutrient availability determines dimethyl sulfide and isoprene distribution in the eastern Atlantic Ocean. Geophys Res Lett 41:3181-3188

\section{Appendix.}

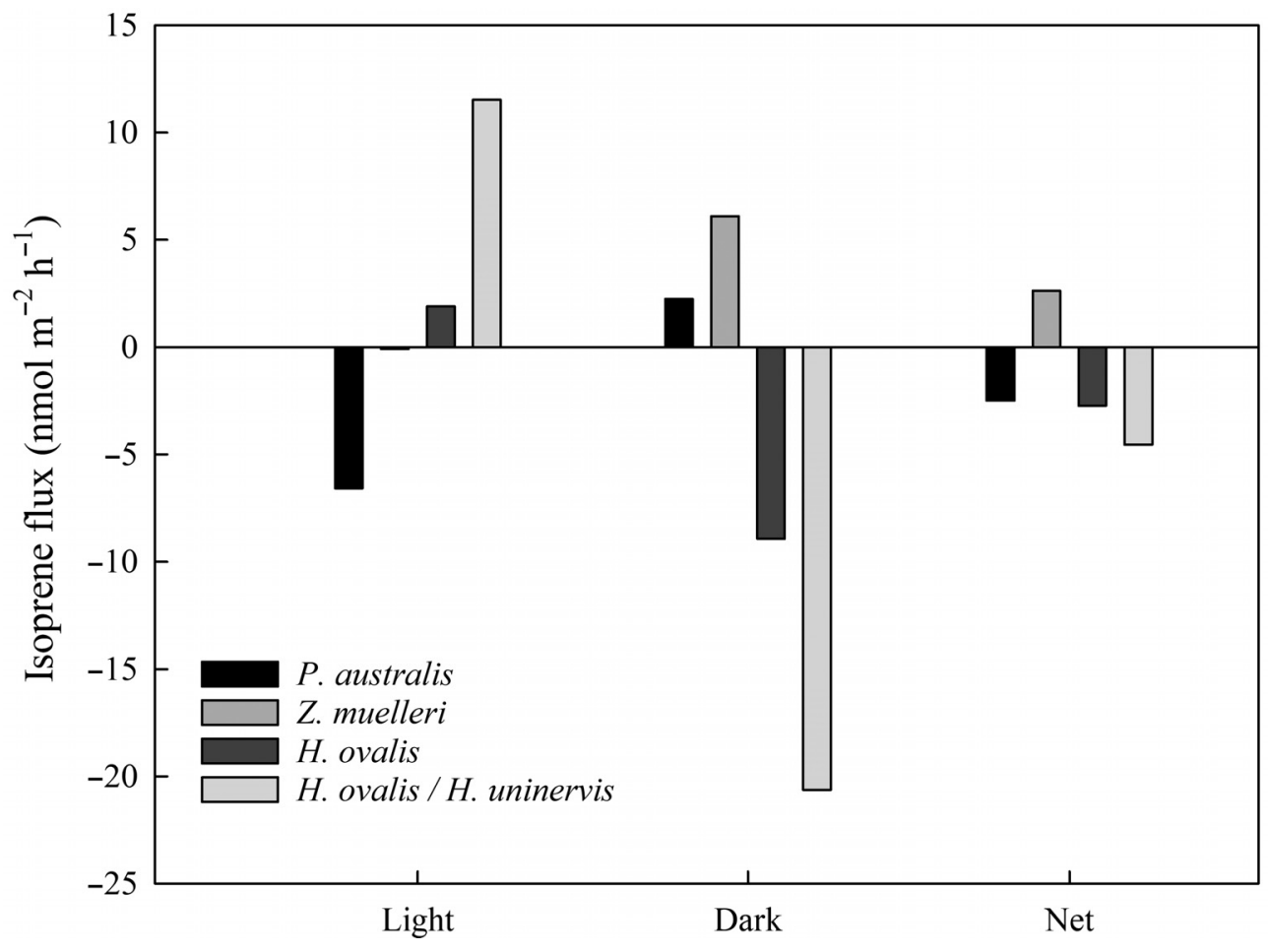

Fig. A1. Light, dark, and net isoprene fluxes within false bottom blank chambers in conjunction with incubations over 3 species of seagrass ( $P$. australis, Z. muelleri, and Halophila ovalis) in Wallis Lake and one mixed seagrass bed containing H. ovalis and Halodule uninervis on Lizard Island $(n=1)$

Editorial responsibility: Robinson Fulweiler

Boston, Massachusetts, USA

Reviewed by: 2 anonymous referees
Submitted: March 6, 2021

Accepted: July 12, 2021

Proofs received from author(s): October 5, 2021 